\title{
OVER DEN ZIN VAN HET JAVAANSCHE DRAMA.
}

\author{
DOOR \\ DR, W. H. RASSERS.
}

In mijn proefschrift heb ik een poging gedaan om eenig licht te verspreiden over het Javaansche wajangtooneel en de daarop vertoonde drama's door deze te plaatsen in het kader van een bepaalden, op Java lang verdwenen, vorm der menschelijke samenleving ${ }^{1}$ ). Ik waagde het toen de onderstelling uit te spreken dat het verlichte wajangscherm den stam voorstelt, en dat de bij het spel zoo scherp tegenover elkaar gestelde linkeren rechterzijden van dit tooneel op te vatten zijn als de beide stamhelften. Tot deze meening was ik gekomen doordat eigenaardigheden van den tooneeltoestel, die ook vroeger wel de aandacht hadden getrokken en mij voorkwamen op zichzelf reeds in deze richting te wijzen, thans voor mij diepere beteekenis hadden gekregen, daar zij volkomen pasten in wat zich aan mij had opgedrongen als interpretatie van de mythe, die ik als den onveranderlijken inhoud van iedere lakon was gaan beschouwen. De eenvormigheid van vele Javaansche drama's en hun dikwijls tot in de details afdalende overeenkomst was reeds voor lang opgemerkt; thans meende ik te kunnen vaststellen dat wij bij het wajangspel te doen hebben met een vast samengaan van steeds denzelfden ritus met in wezen steeds dezelfde mythe. Naar mijne aanvankelijke opvatting hield deze laatste in een strijd van de wassende-maanfiguur tegen de afnemende maanhelft om het bezit van een vrouw die de volle maan voorstelt, in welken strijd de eerste tracht de den ander rechtens toekomende vrouw te ontvoeren en waarin de afnemende maan ten slotte de overwinning behaalt. Weldra bleek mij echter, dat alleen dan deze verklaring kon worden aanvaard, wanneer bij de

1) De Pandji-roman (1922), blz. 318 vlg.

Dl. 81. 
interpretatie de grenzen van een zuiver naturisme werden overschreden, en wanneer men inzag dat de in deze mythe optredende figuren gerangschikt waren volgens een primitieve stamdeeling in twee exogame phratries. Eerst op deze wijze beschouwd ging er volledig licht op over de gedragingen van deze figuren. In eigenlijken zin bleek de stam-organisatie de achtergrond van het wajangspel te zijn; en verder onderzoek deed mij besluiten dat in haar oorspronkelijken, typischen vorm de mythe een soort cosmogonie is die het aardsche bestaan verhaalt van de goddelijke voorouders der beide phratries: hoe deze geboren worden en opgroeien, de pijnen der initiatie hebben te doorstaan, en ten slotte met elkander in het huwelijk treden. Met de onvermijdelijke en vanzelfsprekende veranderingen die moesten ontstaan, doordat hier geen sprake is van gewone stervelingen, maar van twee met goddelijke macht begaafde wezens die aan den aanvang der tijden staan en zelf de scheppers zijn der wereld en de inrichters van den stam, bleken de lotgevallen van de beide mythische representanten der stamhelften een trouwe weerslag van wat ieder tot een huwelijk bestemd menschenpaar in een primitieve maatschappij, georganiseerd in exogame groepen, heeft door te maken.

In deze korte karakteristiek zijn de typische trekken van deze mythe, in hoe tallooze, sterk gevariëerde redacties zij ook voorkomt, reeds aangegeven. Als eerste, vast aanwezig kenmerk vindt men: de twee-deeling; steeds staan twee hoofdfiguren of twee groepen van hoofdfiguren (doch die dan in wezen aan elkaar gelijk zijn) tegenover elkander; deze twee helden worden gedacht als volkomen elkaar's gelijken, dikwijls heeten zij tweelingen; zij behooren onverbrekelijk bij elkander, vormen zelfs te zamen een eenheid, en toch komt het ook telkens weer uit, dat zij elkaar min of meer afstooten en - zooals dat van stamgenooten uit verschillende phratries te verwachten is - in eenigszins vijandige verhouding tot elkaar staan. Soms vangt in verband met de stameenheid bòven de gescheidenheid der beide primaire groepen - de mythe aan met een hoogere, oorspronkelijke eenheid, en dan worden de voorouders der stamhelften wel voorgesteld als op miraculeuse wijze ontstaan uit één wezen (man of vrouw), dat in vreeselijke ascese de kracht had verworven tot deze scheppingsdaad. In andere gevallen vormen de phratries zelf den aanvang der schepping, en deze 
beide figuren heeten dan veelal vader- en moederloos. Hunne verhouding tot elkaar wordt niet altijd eender voorgesteld; soms zijn zij broeders en dan raak tweelingbroeders, waarbij echter de linker-phratrie toch altijd geldt als iets ouder dan de rechter; meer gewoon is het, dat zij zuster-en-broeder zijn, soms ook moeder-en-zoon of vader-en-dochter. Daar, bij verschillend geslacht, deze beicle figuren - van wege het karakter der phratries van primaire, exogame groepen - van nature bestemd zijn om met elkaar in het huwelijk te treden, ontstaat vanzelf het incest, dat eveneens een vrijwel doorloopend voorkomenden trek in deze verhalen vormt. Hoewel in den regel van den aanvang af vrij duidelijk op dit huwelijk van de twee voornaamste figuren gezinspeeld wordt, is het toch ook niet ongewoon, dat zij elkaar gedurende eenigen tijd schijnen te ontvlieden en afkeer toonen van het huwelijk; zonder twijfel is in dit detail de mythische weerslag te zien van het in samenlevingen als die den achtergrond van deze verhalen vormen vast geldende voorschrift, dat jongelieden eerst dan aan een huwelijk mogen gaan denken, wanneer zij beiden de inwijdingsproef ten einde toe hebben doorstaan. Deze laatste, de smartelijke in itiatie in het hoogere leven van den stam, de pijnlijke wedergeboorte van jongen en meisje tot volledig man en vrouw, vormt onveranderlijk de kern van dit heele mythische thema. De beide hoofdfiguren heeten eerst on vol kom en, klein-gebleven wezens, geestelijk en lichamelijk onvoldragen, soms wanstaltig; door de initiatie worden zij tot vol ma a k te menschen die in het huwelijk kunnen treden. De wijze waarop deze aan de helden te voltrekken ceremonie in de verschillende vormen van deze mythe wordt verhaald, is uiterst gevariëerd; doch altijd komt het alweer in getrouwe copie van de werkelijkheid die zij hebben te motiveeren - neer op het doorbrengen van een tijd van eenzame af $z$ ondering in leed, onthouding en gevaar. De beide voorouders staan dan buiten de samenleving, zij verdwijnen plotseling of worden te vondeling gelegd, opgesloten, of verbannen naar de wildernis of de bergen; dikwijls vermommen zij zich hierbij, en steeds wacht hen dan een moeilijke en uiterst gevaarvolle taak: zij krijgen ingewikkelde raadsels op te lossen, moeten bezwaarlijk te verwerven zaken opzoeken en daarbij monsters bevechten, enz. enz. Het is een veel voorkomende trek dat de beide initiandi hierbij sterven, of het 
bewustzijn of het geheugen verliezen; in weer andere redacties heet de initiatie een ziekte, waarbij de patiënt soms misvormd is. Maar het slot brengt onveranderlijk de blijde ontknooping: wanneer de ceremoniën zijn afgeloopen, herleven de helden of zij zijn eensklaps genezen van hun kwaal, zij zijn nieuwe wezens geworden met nieuwe namen en andere gestalten, en schijnen vaak hun vroeger bestaan ten eenenmale vergeten. Soms is een ritueel bad noodig, eer zij uit den taboe-toestand, waarin zij zoo lang verkeerden, weer in het gewone leven kunnen terugkeeren. Dan staat niets meer aan de vereeniging der beide voor elkaar bestemde figuren in den weg; zij sluiten een - schijnbaar incestueus - huwelijk, en stichten een rijk, d.w.z. den stam, waarvan zij te zamen de voorouders worden. Strikt genomen steunde deze opvatting van de oorspronkelijke beteekenis van het Javaansche drama slechts op de uitkomsten van de analyse van eenige weinige lakons. Dat ik het niettemin waagde daaruit een zoo algemeene conclusie te trekken kwam vooreerst, doordat de reeds zoo vaak opgemerkte gelijkenis van vele drama's en het feit ook dat zij blijkbaar in de schatting der Javanen alle tot op zekere hoogte voor gelijkwaardig en verwisselbaar gelden, de verwachting wettigde dat wat aan een, zij 't ook klein, deel der tooneelliteratuur geconstateerd werd, van algemeene beteekenis moest zijn. Maar bovenal: het onderzoek moest wel den indruk wekken, dat in de volmaakte overeenkomst van den eigenaardigen bouw van het wajangtooneel met de structuur van de mythe, zooals ik die wenschte te interpreteeren, niet een toevallig samenvallen te zien was van twee in wezen en oorsprong verschillende verschijnselen, maar dat hier essentiëel verband bestond. De classificatie die, naar ik aannemelijk trachtte te maken, uit deze weinige lakons naar voren kwam, bleek volkomen dezelfde als die de tooneeltoestel doorloopend, bij iedere vertooning, te aanschouwen gaf.

Gaat men er nu toe over om aan een grooter aantal lakons de waarde van de door mij voorgestane opvatting van den zin van dit drama te toetsen en zoo tevens de vraag of inderdaad al dez.e tooneelstukken in wezen een-en-denzelfden inhoud hebben, met grooter zekerheid te beantwoorden, dan moet men al spoedig constateeren dat het aantal lakons waar men, ook na aftrek van wat zich direct als bijwerk voordoet, de boven in hoofdtrekken meegedeelde mythe met gemak herkent, betrekkelijk klein is. 
Verwonderlijk is dit echter niet, en het behoeft m.i. ook niet tegen de juistheid van mijne hypothese te pleiten; immers het stellen van den eisch, dat men thans in elke willekeurige lakon deze mythe in gaven vorm en ordelijk verband zal moeten weervinden, kan niet anders dan onwetenschappelijk en dus volkomen onbillijk genoemd worden. Om dit in te zien is het - afgezien van andere factoren die hier wellicht gewerkt hebben - voldoende zich ervan te vergewissen, in welk stadium van zijn ontwikkeling het is dat wij het Javaansche tooneel aantreffen, en van welken aard de lakons, die ons voor onderzoek ten dienste staan, bijna zoncler uitzondering zijn. Hoe men zich n.l. ook den oorsprong van dit tooneel voorstelle, met zekerheid weten wij dat de gemeenschap, waarin deze ritus eigenlijk thuishoort, sinds eeuwen niet meer bestaat. De religieuse beteekenis van de wajang is grootendeels verdwenen, en al vrij lang is zij - enkele uitzonderingen daargelaten - niet veel anders meer dan een wereldsch vermaak. Oude, zinrijke gebaren en voorschriften leven nog voort, doch onbegrepen of misverstaan; de collectieve voorstellingen waarvan de wajang eenmaal de directe uiting was, hebben haar onverzettelijke, dwingende macht over de geesten geleidelijk verloren, en de ruimte, die den dalang voor zijn individueele inventie gelaten werd, is in verband daarmee steeds toegenomen. Als onmiddellijk gevolg hiervan zijn de tooneelstukken, waarvan wij thans de meer of minder uitgebreide teksten vóór ons hebben, voor het meerendeel dan ook niet meer te beschouwen als zuivere, scherp-omlijnde wedergaven van welke mythe ook; zij zijn weliswaar nog geen volkomen vrij, artistiek werk - verre van daar! -, maar zeker moet men er wél in zien sterk persoonlijk gekleurde paraphrasen en bewerkingen van de stof die in het onderstelde, oorspronkelijke thema gegeven was. Onderzoekt men nu lakons van een naar allen schijn zeer ver afgeweken geäardheid, dan ziet men daarin die trekken, die ik hierboven in mijn schema van de oorspronkelijke mythe als typeerende kenmerken naar voren bracht, toch alle of ten deele terugkeeren, - zij 't dan ook uit hun verband gerukt en in vaak onlogischen en elke verklaring weerstrevenden samenhang met elkaar gebracht. Meermalen - telkens n.l. wanneer wij verschillende redactie's van dezelfde lakon bezitten - is het mogelijk het verloop van dit verwordingsproces eenigermate na te gaan; belangrijke details, die in de eene redactie nog voor- 
komen, ontbreken dan vaak in een jongere bewerking of zijn anders gecombineerd en van functie veranderd ${ }^{1}$ ). Voor zoover mijne kennis reikt, zijn dan ook de hier bedoelde lakons met mijne opvatting van de oorspronkelijke beteekenis van het Javaansche drama niet in strijd, maar bevestigen zij die veeleer.

Maar hiermee zijn alle bezwaren niet uit den weg geruimd; en ik moet hier wijzen op een ander verschijnsel dat niet zoo gemakkelijk in overeenstemming te brengen is met de voorgedragen zienswijze, en dat met name de stelling, dat alle lakons zonder uitzondering varianten zouden zijn van een-en-dezelfde mythe, in gevaar brengt. Herhaaldelijk reeds heeft men er de aandacht op gevestigd dat (al is 't zeker niet geheel zonder goeden grond, wanneer men aanneemt dat voor de Javanen alle lakons in zekeren zin gelijkwaardig zijn) er toch een niet te miskennen verband bestaat tusschen het opvoeren van speciale drama's en bepaalde, onderling zeer verschillende, omstandigheden in het leven van individu of gemeenschap. Ook dan is er altijd nog wel zekere speelruimte, maar de voorkeur gaat toch beslist naar vast voorgeschreven, in die gevallen bijzonder geschikt geachte lakons. Prof. Hazeu wees er bijv. op, dat bij de plechtigheid van het reinigen van de desa na den rijstoogst veelal een van de lakons Sri Moelih (= Sri Sědana) of Mangoekoewan wordt opgevoerd; is het al te lang droog geweest en wil men den regenval bevorderen, dan zijn de Watoe-goenoeng en de Windoesědjati de gebruikelijke stukken; en moet iemand tegen een dreigend onheil worden beveiligd of van een vloek worden verlost, dan is men veelal van oordeel dat slechts één lakon daarvoor in aanmerking kan komen, n.l. de Moerwakala ${ }^{2}$ ). Ook de heer Kats maakte opmerkzaam op dit verschijnsel; hij gaf een uitgebreide lijst van deze "gelegenheidsstukken" en deed tevens uitkomen, dat deze veelal zóó gekozen zijn dat het onderwerp verband houdt met den bijzonderen aard van de plechtigheid. Blijkens deze opgave worden dergelijke lakons vooral opgevoerd bij 1 . het sluiten van een huwelijk; 2. het $\mathrm{t}$ ingkěb-feest (zwangerschap van zeven maanden); 3 . de poepak poesĕr-ceremonie (het afvallen van de navelstreng

1) Over de waarde van afwijkingen in verschillende lakon-redacties zie men de opmerkingen van Inggris, in: Het offerfeest "Barit", in Djawa, 2de Jrg. (1922), 158, 1ste kolom.

2) Zie Een Ngruwat-voorstelling, in Album Kern (1903), 325 vlg. 
bij een jonggeborene); 4 . de besnijdenis; 5 . het afleggen van een plechtige gelofte; 6 . het $\mathrm{b} \breve{r} \mathrm{r} \breve{s i h}$ desa (het reinigen van de desa na afloop van den rijstoogst); 7 . de $\mathrm{ng}$ roe wat-ceremonie (het afwenden van speciaal genoemde onheilen) ${ }^{1}$ ). $\mathrm{Nu}$ kan het wel niet anders of hierdoor moet de indruk gewekt worden dat, in verband met den sterk uiteenloopenden aard dezer ceremoniën, ook de daarbij opgevoerde lakons absoluut heterogeen moeten zijn. Is het bijv. a priori waarschijnlijk of zelfs denkbaar te achten, dat twee stukken, waarvan het eene, van wege zijn inhoud, bijzonder passend is voor het besnijdenisfeest, en het andere door zijn agrarische kleur verwantschap vertoont met een landbouwplechtigheid als het berrěsih desa, toch in wezen gelijk zouden zijn en slechts varianten van het ééne, hierboven geschetste thema?

Bij nadere overweging blijkt echter spoedig, dat deze indruk, althans voorzoover het betreft de onder 1 tot 5 genoemde plechtigheden, onjuist is. Het bestaan van lakons die voor deze vijf gelegenheden meer in het bijzonder geschikt geacht worden, behoeft niet te verwonderen en gaat zelfs uitmuntend samen met het aannemen van een in essentie steeds gelijken mythischen inhoud van alle lakons, wanneer ten minste mijne interpretatie van die mythe aanvaard wordt. Als de voornaamste motieven ervan merkten we immers op: de geboorte, de initiatie en het huwelijk der beide voorouders; en men kan dus zeggen dat er een natuurlijke affiniteit bestaat tusschen deze mythe en alle onder 1 tot 5 genoemde critieke omstandigheden in het leven van ieder individu. Naarmate nu in eenige lakon iets meer nadruk gelegd werd op één van deze hoofdmotieven en de andere daartegenover een weinig terugtraden, werd de verwantschap met een bepaalde omstandigheid sterker en de geschiktheid voor een speciale ceremonie grooter; en zoo moesten vanzelf bijzonder aangewezen gelegenheidsstukken ontstaan, zonder dat hierbij sprake is van een wezenlijke afwijking van den algemeenen lakon-inhoud.

Voor de lakons echter, die opgevoerd worden bij landbouwceremoniën als het běrěsih desa en bij de ngroewatplechtigheid, gaat deze verklaring niet op; en hier stuiten we dus op een wezenlijk probleem. De moeilijkheid wordt nog ver-

1) J. Kats, Het Javaansche tooneel, dl. I (1923), 108-109. 
groot doordat ook in ander opzicht deze zelfde lakons een aparte plaats schijnen in te nemen en vermoedelijk van groot belang zijn. Een eerste aanwijzing hiervoor is, dat juist bij opvoeringen van deze stukken het ouderwetsche, religieuse karakter van de wajang nog het best bewaard is gebleven; en verder merkte Kats op, dat het bij deze ceremoniën, die hij specifiek Javaansche gebruiken noemt, oer-oude Indonesische mythen zijn die ten tooneele worden gevoerd, terwijl voor andere gelegenheden Indische verhalen worden gebruikt ${ }^{1}$ ). Hoe dit laatste nu ook zij, in ieder geval springt het reeds bij oppervlakkige lezing in het oog, dat de lakons die bij het berěsih desa opgevoerd worden, een uitgesproken agrarische kleur dragen, veel minder doorzichtig zijn en zich niet zoo gemakkelijk leenen voor een analyse die ze een plaats zou geven in het kader van de mythe die wij aanzagen voor het eenige wajangthema; en wat de Moerwakala betreft, men moet er wel aan wanhopen ooit in dit verhaal een cosmogonie te kunnen aanwijzen als die ik in het overige repertoire meende te vinden.

Moeten wij hieruit nu besluiten dat de meening dat wij bij de wajang te doen hebben met een vaste solidariteit van ritus en mythe - hoe waarschijnlijk die op zichzelf ook zij - toch onjuist is? Zijn wellicht van den aanvang af op dezelfde scène geheel verschillende mythen vertoond? Is er reden om een essentiëel onderscheid te maken tusschen de stukken, die bewerkingen zijn van echt-Indonesische verhalen, en de lakons zooals zij onder Indischen invloed geworden zijn; en hebben wij dan hier te doen met een geval waarin een ritus van mythe veranderde? ${ }^{2}$ ) Of moeten wij er toe overgaan om onze geheele opvatting van den zin van het Javaansche drama te herzien?

Ik meen geen overbodig werk te doen door te trachten dit vraagstuk een weinig nader tot zijn oplossing te brengen; en ik stel mij voor daartoe in de volgende bladzijden eenige van die bij de landbouwplechtigheden vertoonde stukken en voorts ook de Moerwakala-lakon in bijzonderheden na te gaan. Daarmee wil ik tevens verbinden een onderzoek van een ander verschijnsel uit de Javaansche folklore, dat oogenschijnlijk met

1) O. c. blz. 109. Zie ook Hazeu, Een Ngruwat-voorstelling, 325, 326.

2) Vgl. H. Hubert, Le Culte des Héros et ses conditions sociales (Préface à Saint Patrick; Hérosnational del'Irlande, par Stanislas Czarnowski). pag. LXVII. 
het onderwerp van deze verhandeling niets uitstaande heeft, n.l. van het $\mathrm{Ni}$ Towong-spel. De redenen hiervoor zullen in den loop van dit opstel vanzelf voor den dag komen en, naar ik vertrouw, worden gebillijkt. Trouwens, al zou de meening dat hier een zeker verband aan te nemen is, ten slotte niet worden gedeeld, ook op zichzelf beschouwd is een dergelijk onderzoek belangrijk genoeg. Men mag verwachten waardeering te vinden voor iedere poging om tot een verklaring te komen van een curieus cultuuroverblijfsel dat naar aller meening teruggaat op een oude, religieuse plechtigheid, waarvan wij de mythe alleen kennen uit de woorden van voor ons grootendeels onverstaanbaar geworden liedjes, en de ritueele gebaren nog slechts kunnen opmaken uit het verloop van een thans ras verdwijnend kinderspel.

I.

Wanneer op de sawah's de rijstaren geel geworden zijn en de gewichtige tijd van den padi-oogst is nabijgekomen, dan pleegt de Javaansche landman, voorzoover hij de oude adat nog in eere houdt, zich tot een doekoen te wenden, opdat deze voor hem een gunstigen dag bepale om met het snijden te beginnen, en verder de leiding op zich neme van allerlei ceremoniën die, blijkens de mantra's die daarbij worden uitgesproken, ten doel hebben Boq Sri en Djaka Sedana (Vrouwe Sri en Jonkman Serdana) uit den hemel te doen nederdalen. De nacht, die aan het begin van den oogst voorafgaat, moet door den ḍok koen wakend worden doorgebracht, en, om hem dit niet te zwaar te doen vallen, geeft de eigenaar van het veld dan wel een djagongan (gezellig samenzijn); soms is daaraan ook een wajangpartij verbonden, en men kiest daarvoor dan steeds de lakon Sri S edana ${ }^{1}$ ). Een dergelijke opvoering heeft ook wel plaats, als de rijstoogst is afgeloopen, bij het běrěsih desa, d. i. de plechtigheid van het reinigen van de desa, wanneer een algemeene schoonmak wordt gehouden, wegen en waterleidingen worden hersteld, het onkruid gewied en de velden voor den nieuwen oogst bereid. Ook dan wordt in den regel de lakon Sri Moelih (=Sri Sedana) of de

1) Alb. C. Kruyt, Gebruiken bij den rijstoogst in enkele streken op Oost-Java; in: Mededeelingen van wege het Nederlandsche Zendeling genootschap, XLVII (1903), 125 vlg. 
lakon Pakoekoewan (= Mangoekoewan of Taněm toewoeh) vertoond ${ }^{1}$ ).

Blijkens het korte referaat dat dr. Kruyt, in zijn zooeven geciteerd artikel, van de lakon Sri Sěda na geeft, komt de inhoud ervan zoo goed als geheel overeen met het drama dat door $\mathrm{Te}$ Mechelen in zijn verzameling wajangstukken is gepubliceerd onder den titel Sri Mahapoenggoeng ${ }^{2}$ ). In vertaling luidt dit stuk als volgt:

Sri Mahapoenggoeng, vorst van het rijk Mẹndangkamoelian. Zijn patih Ki Djaka Poering, zijn verwanten Ki Andong en Ki Daḍapan, de hofnarren Kjaï Boejoet, Ki Toewa en Ki Poetjangkoet, voorts Kjaï Wijoengjang en $\mathrm{Ki}$ Tjandramawa maken hun opwachting bij hem. Het gesprek loopt over de verdwijning van 's vorsten zoon, prins Sedana; de patih bericht dat hij nog niet gevonden is. Men wordt gestoord door de komst van een gezantschap uit Mẹṇangkoemoewoeng; een der boeta's, met name Kaladaroe, wordt voor den vorst ontboden; hij heeft een brief bij zich. De vorst beveelt den patih den brief in ontvangst te nemen en voor te lezen; hij houdt een huwelijksaanzoek in voor de prinses Dewi Sri: "wanneer zij reeds verloofd is, dat dan die verloving verbroken worde; is zij al gehuwd, men doe haar scheiden van haar echtgenoot; wordt een vergoeding geëischt, wat moet dit dan zijn? voor dit leed geeft goud gemakkelijk troost». De vorst antwoordt: «Wil eerst een oogenblik wachten, ik zal overleg plegen». Hij trekt zich terug in zijn paleis bij zijn drie gemalinnen Dewi Grmi, Dewi Nastiti en Dewi Soeboer, en zijn dochter Dewi Sri. Aan de laatste deelt hij mee, dat zij ten huwelijk zal worden gegeven aan Koning Poelagra, den vorst van Menduangkoemoewoeng; "och (zegt hij), stem maar toe, heb deernis met uw rijk.» De prinses verzet zich echter; «ik ben er wel toe bereid, wanneer hij in zijn manieren is als mijn jongere broeder Sědana.» "Hé! zoo! waarom wil je mijn bevel niet opvolgen?» "Mijn antwoord luidt: ook al moet mijn weigering mij het leven kosten, het zij zoo!» «Maak je dan weg

1) G. A. J. Hazeu, Een Ngruwat-voorstelling, (Album Kern, 325).

2) Ch. Te Mechelen, Drie-en-twintig schetsen van wajangstukken (lakon's), gebruikelijk bij de vertooningen der wajang-poerwa op Java; in: Verhand. van het Bataviasch Genootschap van Kunsten en Wetenschappen, XL (1879). Zie blz. 11-18. 
van hier!" - Dewi Sri neemt dan afscheid en gaat heen met als gevolg slechts ééne dienstmaagd; haar moeder klemt zich aan haar vast om haar terug te houden, doch te vergeefs; zij gaat heen. - Vervolgens ontbiedt de vorst den patih Poering: "Patih, deel gij aan Kaladaroe mee, dat mijn dochter onwillig is; zij heeft er de voorkeur aan gegeven weg te gaan; laat hij maar zoeken waar zij is; als zij gevonden wordt, kan hij haar grijpen; ik geef daartoe mijn toestemming." De patih verwijdert zich en heeft in de audiëntiezaal een onderhoud met Kaladaroe, Kalasrana, Kalajěksa. Vervolgens gaan allen op zoek naar de vluchtelinge; zij snuiven, en de geur is merkbaar; op dien geur gaan zij af. Spreken wij nu over de nederzetting Mẹnạangtamtoe. Een zekere Boejoet Wangkenng zit neer met zijn vrouw; hun gesprek loopt over het drogen van de pas gesneden rijst, den volgenden middag moet zij worden binnengehaald. Dan verschijnt plotseling Dewi Sri in het rijstblok; de vrouw van Boejoet Wangkeng noodigt haar in huis te komen. Dewi Sri zegt: "Ja, ik wil wel binnenkomen, maar wanneer er soms kippedrek ligt, maak 't dan eerst schoon». Het huis wordt gereinigd, en vervolgens treedt Dewi Sri binnen. Zoodra zij gezeten is, zegt zij: «Roep uw man eens hier.» Tot dezen zegt zij: "Ik kom hier maar even aan», en zij vraagt om een dronk klapperwater. Na gedronken te hebben, neemt zij afscheid; Kjaï Boejoet tracht haar nog te weerhouden, maar zij wil niet blijven. Terwijl zij nog met elkander praten, verschijnt Kaladaroe en eischt dat Dewi Sri, die door hem achtervolgd wordt, aan hem zal worden uitgeleverd. Boejoet Wangkěng stemt daar niet in toe, en zij vechten met elkaar; Boejoet Wangkeng delft het onderspit, en hij wordt vastgebonden aan een $n$ angka-boom. Dewi Sri bemerkt dat hij de nederlaag lijdt en maakt zich uit de voeten; en zonder ophouden wordt zij achtervolgd door Kaladaroe, Kalasrana en Kalajěksa.

Batara Goeroe en Nerada komen op. Goeroe vraagt verwonderd: "Nerada, wat is dit? Wie is 't die deze wonderlijke natuurverschijnselen veroorzaakt?» Nerada antwoordt: ‘Die zijn een gevolg van het van huis weggaan van Dewi Sri; haar werd voorgesteld te trouwen met een afstammeling van Poețoet Djantaka, maar zij wilde niet». Goeroe zegt: "Geen wonder dat zij niet wilde; broeder, daal gij naar beneden en wijs haar waar haar broeder Sedana zich ophoudt». Nerada daalt neer en komt bij Dewi Sri; hij zegt tot haar: *Uw broeder houdt zich op in het 
woud van Meṇ̣ạang-agoeng.» Vervolgens stijgt Nerada weer naar boven.

Prins Sedana in het woud van Mẹṇang-agoeng; Ki Boejoet, $\mathrm{Ki}$ Toewa, Ki Poetjangkoet vormen zijn gevolg. Ki Toewa zegt: aIk verzoek Uwe Hoogheid dringend toch naar huis terug te keeren.» "Ja, ik ben bereid terug te keeren, zoodra mijn zuster eerst gehuwd is; zoolang dat niet gebeurd is, zou 't maar uitstel veroorzaken in haar huwelijk.» Kort daarop verschijnt Dewi Sri, en weenend omhelst zij hem; wanneer het weenen opgehouden is, zegt Sedana: "Waarom zijt gij toch uit ons land weggegaan?" Dewi Sri verhaalt hoe zij er toe kwam heen te gaan: "hoor eens! god Nerada was 't, die mij er last toe gaf.» Sedana zegt: "Wat was de aanleiding daartoe?» en haar antwoord luidt: «De aanleiding tot mijn heengaan lag hierin, dat Vader mij voorstelde te huwen met den koning van Mẹṇangkoemoewoeng, uit het geslacht van Djantaka; ik wilde zijn wensch niet opvolgen en daarom werd ik verbannen». Terwijl zij nog met elkander spreken, komt Kaladaroe en eischt Dewi Sri op. Sědana weigert en zij raken slaags. De boeta kan niet worden gedood; maar dan wordt een windpijl op hem afgeschoten, en hij verdwijnt. Sri en Sèdana overleggen met elkaar om een nederzetting te stichten in het woud van Meṇ̦ang-agoeng. Prins Sědana wordt door zijn zuster naar MÆṇḍanggowong gezonden: "vraag daar zaden aan $\mathrm{Ki}$ Boejoet Sondong: uitgeloopen kokosnoten, rijst, obi, g ̌mbili, kimpoel, Spaansche peper, terong'. Prins Sedana vertrekt, met Ki Boejoet en Ki Poetjangkoet.

Te Mendạnggowong. Ki Boejoet Sondong en zijn vrouw; de eerste spreekt: "Zeg, vrouw, als Prins Sedana hier op bezoek komt, wordt hij op ongemeene wijze onthaald: gij slacht kippen, laat bloemen voor boreh koopen! Het is werkelijk overdreven! Maar als ge voor mij eten klaarmaakt, dan is 't maar zooals 't valt». "Natuurlijk! als men den vorst te gast heeft! Zooveel mogelijk tracht ik de eer van uw huis op te houden!s Terwijl zij zoo zitten te praten, komt Prins Sedana daar aan; Boejoet Sondong noodigt hem uit plaats te nemen en draagt zijn vrouw op in de keuken eten klaar te maken; sbemoei je maar niet met de receptie van den gast, dat zal ik zelf doen». Sedana zegt: „Oom, maak geen moeite voor mij, ik zal niet lang toeven; ik ben door mijn oudere zuster hierheen gezonden met de opdracht om zaden te vragen: uitgeloopen klappers, obi, 
g ̌̌mbili, kimpoel, Spaansche peper en terong. En voor mijzelf zou ik ook nog omheiningsmateriaal willen hebben; wij houden verblijf in het woud; en roep al uwe onderhoorigen, die hier in het woud wonen, voorzoover het werkbare mannen zijn, bijeen». Boejoet Sondong antwoordt: "Om $U$ te dienen, ga $U$ maar eerst terug; ik zal er last toe geven.» Nadat Prins Sedana is heengegaan, vertrekt ook Boejoet Sondong met al zijn onderhoorigen.

Dewi Sri. Prins Sedana komt aan en deelt mee dat hij geslaagd is; weldra komt ook Boejoet Sondong die de zaden aanbiedt. Daarop wordt bevel gegeven om de omheining in elkaar te zetten en er een deur aan te maken. Dewi Sri zegt tot haar broeder: "Ik zend u naar Menḍangtamtoe, maak daar Boejoet Wangkeng los en breng hem met zijn vrouw hierheen». Sědana gaat op weg.

M̌ṇdangtamtoe. Boejoet Wangkěng is nog altijd vastgebonden aan den nangka-boom; door zijn vrouw wordt hem eten in den mond gestopt. Sědana komt op; Boejoet Wangkeng wordt losgemaakt en met zijn vrouw ontboden. $\mathrm{Zij}$ vertrekken.

De vorst van Mẹndangkoemoewoeng, koning Poelagra, zijn patih, de boeta Poelasija, en zijn zoon prins Poelasta; zij zien verlangend uit naar de terugkomst van de gezanten. Terwijl zij nog met elkander praten, verschijnt Kaladaroe, die alles vertelt, wat er gebeurd is. - Daarop trekt de vorst op met al zijn rijksgrooten. - Mẹṇang-agoeng; Dewi Sri. Prins Sexdana komt op en brengt Boejoet Wangkěng bij haar; tot dezen zegt Dewi Sri: "Mijn waarde, kom hier wonen en treed in mijn dienst; en laat Mendangtamtoe maar over aan uw kinderen en kleinkinderen . Tijdens hun gesprek ontstaat buiten opschudding; de gewapende benden van Mẹṇangkoemoewoeng zijn aangekomen en aan het plunderen geslagen. Boejoet Sondong trekt hen tegemoet; aan 't hoofd van het leger staat Boejoet Wangkěng. Terwijl zij strijden vertoonen zich wonderteekenen in de natuur.

Goeroe en Nærada. Nerada, door Goeroe gevraagd naar de oorzaak van die wonderteekenen, deelt mee dat Dewi Sri belaagd wordt door een afstammeling van Poețoet Djantaka. God Goeroe zegt: "Bajoe, daal gij met Goeritna en Jamadipati naar beneden, en laat Brama uw leider zijn.» De vier goden tot wie het bevel gericht was, en Nrrada als vijfde, dalen naar beneden 
en bieden hulp. De boeta's worden aangevallen; van sommigen worden de armen afgehouwen, maar zij sterven niet; steeds meer boeta's komen achter hen op. Daarop verwekt god Bajoe een stormwind, en allen vluchten heen. Dan komt Nerada op en roept Sri en Sedana vóór zich; alle goden zijn bijeen. Nerada zegt: "Nu dan, Sri, treed in het huwelijk!» Dewi Sri antwoordt: "Ik weiger het bevel om te huwen op te volgen.» "Gij dan, Sedana, treed gij dan maar in 't huwelijk!, Ook Sedana wil niet. Dan zegt Nerada: «Hoe nu? gij wilt beiden niet in het huwelijk treden?» Dewi Sri zegt: "Ik wil wel huwen wanneer hij is als Sědana.». En Sedana zegt desgelijks: "Ik wil wel huwen wanneer mijn aanstaande vrouw er uitziet als mijn zuster.» Hierop verklaart Nerada: "Goed dan, dan zal ik $\mathrm{u}$ in het huwelijk verbinden met uw zuster!» Sri en Sëdana weigeren beiden. Daarop worden zij door den god gescheiden; prins Sedana wordt verplaatst naar den overwal.

Einde van de lakon Sri Mahapoenggoeng.

Van de lakon Měngoekoehan, die eveneens handelt over de avonturen van de rijstgodin, is in de Leidsche Universiteitsbibliotheek een handschrift aanwezig dat behoort tot de lakonverzameling van dr. Van der Tuuk ${ }^{1}$ ); zooals dr. Juynboll ${ }^{2}$ ) reeds mededeelde, komt de inhoud van dit manuscript geheel overeen met een deel van het bekende mythologische geschrift Manikmaja, en wel met het stuk dat in Winter's vertaling ${ }^{3}$ ) loopt van blz. 31 tot 52. Met deze episode, die slechts gaat tot Tisnawati's dood, zijn echter de rampzalige lotgevallen van de rijst nog niet geheel ten einde gebracht, en een andere redactie van de M ̌ngoekoehan, die zich bevindt in de boekerij van het Bataviaasch Genootschap, gaat dan ook verder; blijkens het korte referaat van dit stuk door Te Mechelen ${ }^{4}$ ) loopt het door tot blz. 79 van de Manikmaja. Hieronder volgt een inhoudsopgave van het stuk volgens het Leidsche hs., voorzoover dit

1) Ms. Or. Cod. 3999.

$\left.{ }^{2}\right)$ dr. H. H. Juynboll, Supplement op den Catalogus van de Javaansche en Madoeresche handschriften der Leidsche Universiteitsbibliotheek, II (1911), 410.

3) Winter, Javaansche Mythologie; in: Tijdschrift voor Neêrlands Indië, 5de Jg. (1843), I, 1-88.

4) Zie: Notulen van het Bataviaasch Gen. v. K. en W., XVII (1879), bijlage II, blz. VII-XI. 
loopt; van het overblijvende deel geef ik de hoofdtrekken volgens Winter's vertaling van de Manikmaja.

God Goeroe, zittend in het paleis Martjoekoeṇa,a, vraagt aan de voor hem verzamelde goden, waar toch de glans, die hij midden op zee bespeurt, vandaan komt. De goden antwoorden dat zij het niet weten; Tamboeroe wordt op onderzoek uitgezonden. De kluizenaar Kanekapoetra doet ascese midden in den oceaan: hij eet niet, drinkt niet, slaapt niet. Weldra komt god Tamboeroe bij hem, maar Kanekapoetra geeft geen geluid. Tamboeroe keert terug en bericht dat het licht uitgestraald wordt door een asceet midden in zee. Goeroe draagt dan alle goden op om den boeteling in zijn ascese te storen; zij volgen het bevel op en komen bij Kanekapoetra, maar deze houdt zich doof voor al hun woorden, en antwoordt niet. God Samboe begiet hem met water, doch de asceet wordt niet nat; Brama brengt door zijn goddelijke vermogens vuur te voorschijn, maar Kanekapoetra wordt er niet door gedeerd. Ontmoedigd aanvaarden de goden den terugtocht en melden dat hun pogingen mislukt zijn. Dan besluit Goeroe er zelf heen te gaan; alle goden vergezellen hem. Bij Kanekapoetra gekomen, vraagt Goeroe dezen, wat hij met zijn zelfkwelling wil bereiken; een schoone vrouw wellicht? Als de asceet niet antwoordt, zegt Goeroe: «Ik weet reeds wat uw wensch is; het zou inderdaad geen zin hebben, dat ik de vorst des hemels ben, zoo ik alles niet wist vóor 't mij wordt meegedeeld; de reden van uw ascese ligt in uw wensch mij te evenaren, doch naar mijn meening is dat onmogelijk, ook al kweldet gij u duizend jaren; want het is door het lot beschikt, dat ik de heer des hemels zijn zou; ik ben de oudste! Ouder dan ik zijn slechts de maan en de zon, en deze worden weer voorafgegaan door de aarde en den hemel; één is er nog die ook boven deze den voorrang heeft: Sang Hjang Wěnang; dezen overtreft niemand.» Lachend spreekt nu Kanekapoetra: "Ik ben Kanekapoetra en ik weet, dat gij Prameștigoeroe zijt, de opperste der goden; als uwe kennis slechts zóóver reikt, dan is het wezen van de Eenheid u nog verborgen. Uw meening dat Hjang Wisesa de oudste is, is onjuist; ten tijde toen er nog chaos was, wat ontstond er toen het eerst?, Nog veel spreekt de asceet Kanekapoetra en Goeroe weet niet te antwoorden; sussend zegt hij: “Wanneer 't u behaagt, zou 
ik wel willen dat gij, mijn oudere broeder, mij inlichtingen gaaft; ik wil u meenemen naar het hemelrijk en zal u het bevel geven over alle goden; wie u zou weerstreven, zou ik niet meer als kind erkennen.» Ook de goden stemmen hier mee in, en Kanekapoetra gaat mee naar den hemel. Daar aangekomen, zet Goeroe zich neer in het paleis Martjoekoeṇda; lang staart hij naar Kanekapoetra's hand, en eindelijk vraagt hij waarom hij die voortdurend gesloten houdt. Kanekapoetra antwoordt dat hij daarin een juweel heeft, Rětna doemilah, waarvan de magische kracht zoo groot is dat wie haar bezit ongevoelig is voor honger en slaap, niet nat wordt door water en niet gedeerd door vuur. Goeroe verzoekt hem dat juweel te toonen; Kanekapoetra is daartoe bereid, doch waarschuwt dat het kleinood zeer scherp is en bij het aangrijpen door de hand heen zal gaan en als een pijl kan wegschieten Maar Goeroe blijft aandringen; alle goden moeten mee oppassen dat het kostbare kleinood niet ontsnapt. Dan werpt Kanekapoetra hem de R etna doemilah toe, Goeroe grijpt met bei zijn handen, doch het schiet weg. De goden trachten 't nog tegen te houden, doch zij missen, en het juweel valt neer tot in de zevende aarde, waar Antaboga het opvangt en opslokt. Goeroe vraagt: "Broeder, wat nu gedaan?» Kanekapoetra verklaart zich bereid het juweel te gaan zoeken ook al ware 't gevallen tot in de zevende aarde; vol vreugde verneemt Goeroe dit, alle goden moeten hem vergezellen. Overal zoeken zij tot zij ten slotte in de zevende aarde komen bij god Antaboga; op diens vraag wat hij wenscht, antwoordt Kanekapoetra dat hij op zoek is naar de R $е \mathrm{tna}$ doemilah, die het eigendom is van Goeroe; groot zal het loon zijn voor wie het kleinood vindt. Antaboga erkent dat de Rětna doemilah bij hem is; doch in zichzelf denkt hij: «ik moet de kracht van die goden toch eens op de proef stellen!» en met luider stem verklaart hij: "de Rètna doemilah ligt in een doosje, en dit bevindt zich in mijn lichaam; wilt gij dus dit doosje hebben, draagt dan mijn lichaam naar den hemel.» Maar Kanekapoetra antwoordt: „ $U_{w}$ woorden zijn onredelijk: wie zou in staat zijn u te dragen? gij zijt zoo groot als de wereld! gij moet zelf meegaan.» Antaboga antwoordt hierop niet, hij kronkelt zich ineen en houdt zich slapend. Bits zegt Wisnoe: "Die Antaboga wil zich verzetten tegen de goden!, $\mathrm{Nu}$ beveelt Kanekapoetra de goden Antaboga's lichaam binnen. 
te dringen en daar de R $̌$ tna doemilah te zoeken. De goden volgen dit bevel op en dringen binnen door den neus, de ooren, den bek; maar door Antaboga's magische kracht raken zij in verwarring en beginnen elkaar daarbinnen te bevechten. Dan slaat Kanekapoetra voor, dat men Antaboga naar den hemel zal voeren op de wijze zooals men vroeger den berg Djamoerdipa vertilde; Bajoe wordt de draagstok, Endra het touw; en bijna heeft men den hemel bereikt, als Antaboga plotseling verdwenen is. Kanekapoetra ontsteekt hierover in toorn en zal zich bij Goeroe gaan beklagen.

Goeroe zit in het paleis Martjoekoenda; de slang Antaboga komt aan zijn voeten liggen. Kanekapoetra verschijnt en, Antaboga ziende, begint hij zijn misnoegen over diens gedrag te uiten. Maar Goeroe sust hem en beveelt Antaboga thans de Retna doemilah te voorschijn te brengen. Deze voldoet daaraan, en Goeroe wil het doosje openen, maar hij kan het niet. Ook Kanekapoetra is er niet toe in staat, evenmin als de goden en Antaboga zelf. Dan neemt Goeroe het doosje en werpt het neer, zoodat het stuk valt; daaruit komt dan een klein meisje te voorschijn, van buitengewone schoonheid en ongeveer drie jaar oud. Tezelfdertijd ontstaat ook het paleis Marakata. Het meisje krijgt den naam Ken Tisnawati. Hierop trekt Goeroe zich met de goden in den hemel terug.

Ken Tisnawati verblijft in de bale Marakata; als zij veertien jaar oud geworden is, is haar schoonheid nog toegenomen, zoodat Goeroe in liefde voor haar ontsteekt; hij vergeet zijn vrouw Oema, en verheft Tisnawati tot zijn tweede gemalin. Hij wil ook het huwelijksgenot met haar smaken, maar zij verzet zich: zij is slechts bereid hem ter wille te zijn, wanneer eerst eenige wenschen van haar vervuld worden. $\mathrm{Zij}$ verlangt een gewaad dat niet verslijt; spijs die, ééns gegeten, voor het geheele leven verzadigt; en de gamělan kétopyak. Goeroe belooft haar wenschen te vervullen, en geeft opdracht aan god Tjitragotra om naar Noesa Kambangan te gaan ten einde Kala en diens zoon Kalagoemarang te ontbieden.

Goeroe in het paleis Martjoekoenḍa, met Kanekapoetra. Kala en zijn zoon verschijnen vóór hem. Aan den laatste geeft hij opdracht de drie door Tisnawati gewenschte zaken voor hem te zoeken; als hij slaagt, zal Goeroe hem tot hofnar in den hemel en op aarde aanstellen; geen der goden mag hem iets in den Dl. 81. 
weg leggen. Kalagoemarang gaat op weg, over zijn hoofd buitelend en luid schaterend en zich allerlei vrijheden veroorloovend tegen de goden, die in woede ontsteken en den wensch uiten, dat hij niet meer in den hemel moge terugkeeren en in een dier moge veranderen.

Dewi Sri in den tuin Bandjaran Sari. Terwijl zij aan het baden is, komt Kalagoemarang op haar af; huilend gaat zij op de vlucht. $Z_{i j}$ komt bij god Wisnoe en op diens vraag, wat haar scheelt, verhaalt zij dat Kalagoemarang haar wilde grijpen en haar nog steeds achtervolgt. Weldra komt Kalagoemarang daar aan, en Dewi Sri vlucht sidderend verder. Kalagoemarang onderzoekt bij Wisnoe wie de echtgenoot is van de vrouw die zooeven in den tuin aan het baden was; als Wisnoe erkent dat dit zijn vrouw is, verklaart Kalagoemarang: "Dan eisch ik uwe vrouw van $u$ !, Wisnoe berust daarin, als zijzelf tenminste wil. Hij roept haar en brengt haar Kalagoemarang's wensch over, maar zij verklaart liever te sterven dan zich hierin te schikken. Kalagoemarang blijft echter aandringen; en Wisnoe fluistert nu zijn vrouw in de vlucht te nemen naar Meṇạangkamoelan en daar in te gaan in het lichaam van de gade van koning Mengoekoehan; hijzelf zal zich incarneeren in dien vorst. Dewi Sri volgt den raad op en ook Wisnoe zelf verdwijnt. Kalagoemarang ontsteekt in toorn en achtervolgt Dewi Sri voortdurend; hij komt midden in een woud, en na drie dagen wordt Sri daar bijna door hem gegrepen. Dan schiet Wisnoe pijlen op hem af die in rotanstengels veranderen; daarin raakt Kalagoemarang met zijn voeten verward, zoodat hij neervalt. Dit ontlokt aan Dewi Sri de opmerking: "Die Kalagoemarang lijkt wel een varken!» En op die woorden verandert Kalagoemarang in een varken.

In Mæṇdangkamoelan; de voorvader der vorsten van Java, M̌ngoekoehan, zit op zijn troon met zijn echtgenoote Darmanastiti. Wisnoe en Dewi Sri verschijnen en vereenigen zich met den vorst en de vorstin.

God Goeroe met Ken Tisnawati in het paleis Marakata. Hij heeft vernomen, dat Kalagoemarang in een varken is veranderd en niet naar den hemel kan terugkeeren. Opnieuw dringt hij er bij Tisnawati op aan dat zij zich met hem zal vereenigen, doch zij weigert. Dan grijpt hij haar met geweld en voert haar naar het slaapvertrek. Tisnawati sterft. God Goeroe is zeer bedroefd; hij ontbiedt Kanekapoetra en draagt dezen op het lijk te ver- 
voeren naar de aarde, en wel naar Meṇdangkamoelan; daar moet hij een stuk bosch omhakken en afbranden, en het lijk begraven. Alzoo geschiedt. Na eenigen tijd komt uit Tisnawati's hoofd een kokospalm voort, uit het schaamdeel rijst, uit de handpalmen pisang, uit de tanden mais. Spoedig wordt de rijst zeer menigvuldig; de zorg ervoor is toevertrouwd aan Ki Boejoet, $\mathrm{Ki}$ Toewa en Ki Poetjakoet, allen staande onder bevel van den broeder des konings, Djaka Poering. - Ook een a ren-palm groeit hoog op.

De god die de noord-oostelijke wereld bewaakt, Pritandjala, vraagt zich verwonderd af waar zijn broeders Kanekapoetra en Wisnoe toch gebleven mogen zijn. Door de lucht vliegend, bemerkt hij aan den zoeten geur, dat er in Mæ̣nḍangkamoelan zeer bijzondere gewassen groeien; hij daalt neer, verandert zich in een èmprit, en gaat zich aan de rijst te goed doen. Djaka Poering ontdekt dit en smijt met een stuk hout naar den vogel, die zich verbergt tusschen de bloemstengels van den aren-palm.

Ondertusschen heeft Dewi Sri zich geheel met Dewi Tisnawati vereenigd. Ook in zijn dierengedaante blijft Kalagoemarang haar achtervolgen, hij komt op de rijstvelden, vertrapt het gewas en wroet den grond om. Wisnoe schiet een pijl op hem af, die hem geheel doorboort; uit het bloed ontstaan allerlei insecten en ziekten die het rijstgewas belagen; Kalagoemarang's misdadige ziel gaat over in het lichaam van de kinderen van Djantaka.

De god Pritandjala blijft steeds het rijstgewas schade toebrengen, en de wakers kunnen dit niet verhinderen daar hij zich altijd verschuilt tusschen de bloemstengels van den arenpalm. Djaka Poering geeft daarom bevel die stengels af te snijden. Wanneer dit geschiedt, vloeit daaruit een vocht dat een zeer zoeten geur verspreidt. Het wordt in een stuk bamboe opgevangen, en Djaka Poering, die de buitengewone waarde ervan beseft, biedt het den koning Mengoekoehan aan. Deze op zijn beurt laat den zoeten palmwijn door Kanekapoetra naar god Goeroe brengen.

Verder wordt verhaald van den asceet Poețoet Djantaka en zijn vele kinderen. Deze hebben allen de gedaante van dieren: de oudste van een groote, witte rat, de tweede van een varken, de derde van een aap, de vierde van een buffel, verder van 
wilde stieren, een reebok, een hert, enz. Door honger gedreven, komen zij met vele volgelingen op de veldgewassen van Menduangkamoelan af, en richten vreeselijke schade aan. De wakers slapen, en als zij wakker worden, blijken zij niet tegen het schadelijke gedierte, dat over magische kracht beschikt, opgewassen. $Z_{\mathrm{ij}}$ melden dit aan koning Mengoekoehan en deze trekt daarop met zijn heele leger uit, maar ook zijn tegenstand is nutteloos; dan zendt hij Poering naar Menḍang-agoeng om hulp te vragen bij zijn broeders, de asceten Andong Daḍapan en Gading Pangoekir. Deze ontvangen den gezant vriendelijk en wijzen hun zoons Sengkan en Toeroenan aan, om hem van dienst te zijn; ieder van deze laatsten geeft een dienaar mee. Deze dienaren hebben een schrikwekkend, wanstaltig uiterlijk; zij heeten Wajoengjang en Tjandramawa. Bovendien ontvangt de gezant een met geheimzinnige teekens versierde, tooverkrachtige lans, en een stuk bamboe waarmee hij, door er mee te slaan, Sengkan en Toeroenan te hulp kan roepen.

Mengoekoehan's gezant gaat met de beide dienaren en de geschenken terug naar Meṇ̣angkamoelan. Thans begint daar de strijd tegen de belagers van de veldgewassen opnieuw; na een hevig gevecht laten van Djantaka's zonen het varken, de aap en de rot het leven. Maar de anderen geven den moed nog niet op; thans trekken de wilde stier en de buffel er op uit en hebben weldra de rijstvelden bereikt. Wajoengjang en Tjandramawa gaan hen weer onverschrokken tegemoet, maar ondanks deze heldhaftigheid zijn zij tegen deze beide tegenstanders niet opgewassen. Dan geeft Poering een slag met het stuk bamboe dat hem meegegeven is, en terstond staan Sengkan en Toeroenan vóór koning Menngoekoehan, en maken zich gereed om hulp te bieden. Uit hun mannelijk lid brengen zij lange einden rotan te voorschijn, die zij als zweepen gebruiken in hun strijd tegen den stier en den buffel. Nauwelijks hebben deze dieren een zweepslag gekregen of zij vallen machteloos neer; een touw wordt hun door den neus gehaald en zij worden aan een grooten boom gebonden.

$$
\text { ** * }
$$

Het kan niet anders of reeds bij een eerste, oppervlakkige lezing moet men bemerken, dat wij hier met landbouw mythen te doen hebben: de eigenlijke inhoud van deze verhalen of ten minste een voornaam deel ervan wordt gevormd door bepaalde 
voorstellingen omtrent den oorsprong van den landbouw en speciaal van de rijstcultuur. Die voorstellingen komen in zooverre met elkaar overeen, dat in beide verhalen het ontstaan of de verbreiding van den rijstbouw te danken is aan een daad der goden, maar overigens wijken zij sterk van elkaar af: in de eerste lakon haalt prins Sedana, op aanwijzing van zijn van het hof verbannen oudere zuster Dewi Sri, eenvoudig zaden van rijst en andere gewassen bij Boejoet Sondong in Mæṇdanggowóng, om ze in het nieuwe rijk te gaan voorttelen, - in het andere stuk ontstaat de rijst op wonderbaarlijke wijze uit het lichaam zelf van de gestorven godin Ken Tisnawati, met wie de rijstgodin Dewi Sri zich later vereenigt. In beide verhalen staat de godin van de rijst aan tal van kwellingen en vervolgingen bloot, en de wijze waarop, met name in de lakon M $\times n g o e k o e h a n$, ons die vervolging wordt voorgesteld, als een voortdurende strijd n.l. tegen allerlei plantenziekten en schadelijke dieren, kan de meening doen ontstaan dat het hier zonder meer de werkelijke lotgevallen van het te velde staande gewas, zooals die telken jare weer opnieuw geobserveerd werden, geweest zijn, die den mythendichter tot zijn verhaal geïnspireerd hebben. Maar men bemerkt al gauw dat, al moge dit voor verscheidene details opgaan, de groote bouw van deze mythen door een dergelijke, zuiver natuurmythologische verklaring toch niet duidelijk kan worden. Eigenlijk alle trekken, die deze verhalen gemeen hebben en die dus in de eerste plaats belangrijk geacht moeten worden, blijven bij deze beschouwingswijze volkomen raadselachtig; en op allerlei vragen, die zich noodzakelijk moeten opdoen - wat bijv. de, in vergelijking met Dewi Sri zoo vaag omlijnde, in de schaduw blijvende figuur van haar jongeren broeder of echtgenoot Sedana (Wisnoe) in het verhaal komt doen? wat het plotseling samenvallen en in elkaar opgaan van sommige helden en heldinnen te beduiden heeft? hoe men zich den samenhang te denken heeft tusschen die deelen van de verhalen, die duidelijk landbouwmythen zijn, en andere, waar wij van eenig verband met den rijstbouw niets bemerken? zoekt men langs dezen weg tevergeefs een antwoord ${ }^{1}$ ).

1) Ook prof. Hazeu wees op de duisterheid van deze verhalen: „de eigenlijke beteekenis van de in deze en dergelijke lakons en verhalen optredende personen is nog niet vastgesteld, en 't is de vraag of dit ooit geheel zal gelukken. 't Schijnt wel dat landbouwkalenders en wicheltabellen zoowel op 
Het komt mij voor, dat dit geheel anders wordt, wanneer men er van afziet om zonder meer met onze modern-westersche denkwijze aan een verklaring van deze verhalen te beginnen, en er zich integendeel van doordringt, dat de determineering van de Dewi Sri-figuur als godin van de rijst voor den Javaan iets anders en iets meer beteekende dan voor ons. Houdt men in het oog, dat Dewi Sri's karakter van landbouwgodin haar tevens een vaste, onveranderlijke plaats toewijst in het rangschikkingsstelsel dat heel de Javaansche logica eenmaal moet hebben beheerscht, dan komt er m.i. in het geheel dezer zoo verward en omsamenhangend schijnende mythen een natuurlijk verband, een vast voortschrijdende logische gang, die ze ook voor ons volkomen begrijpelijk maken. Dan vinden we die trekken, die hierboven naar voren gebracht werden als teekenend voor de lakons-in het algemeen, ook hier in denzelfden samenhang terug, en zij hebben er denzelfden zin; en dan wordt het tevens duidelijk dat, voor zoover het deze lakons betreft, een verdeeling van het wajang-repertoire in Indische en Indonesische stukken, in den geest waarin die werd bedoeld, geen reden van bestaan heeft.

In de eerste lakon heet het oudste Javaansche rijk Mẹṇdangkamoelian; het wordt bestuurd door den vorst Sri Mahapoenggoeng die van alles de eenige oorsprong is. Weliswaar heet in het verhaal ook hij reeds gehuwd, maar zijn vrouwen spelen verder geen rol van eenige beteekenis. Uit hem ontstaat duidelijk de tweedeeling: hij heeft twee kinderen, Dewi Sri en prins Sedana. De eerste stelt de linkerphratie voor, de prins is de voorvader van de rechter-stamhelft; Dewi Sri heet dan ook Sedana's oudere zuster. Als voorouders der beide phratries, die door hun voorbeeld het exogame huwelijk moeten instellen, zijn zij voorbeschikt om met elkander in den echt te treden, doch te voren moeten $\mathrm{zij}$ daartoe de inwijdingsceremoniën ondergaan. Als het stuk aanvangt, is de initiatie van Raden Sedana zelfs reeds begonnen: hij is van het hof verdwenen, en welke moeite men ook doet, men slaagt er niet in hem op te sporen. In den verderen loop van het verhaal komen we te

den loop der verhalén als op de persoonsnamen invloed hebben geoefend". (Een Ngruwat-voorstelling, 325, noot 1). Met de laatste opmerking wijst prof. Hazeu in de richting, waarin zich mijn verder betoog beweegt. 
weten dat hij zich ophoudt in Mẹṇangtamtoe, en wel in een woud, d.i. in de omgeving die voor de initiatie de vanzelf aangewezene moet heeten. ${ }^{1}$ ) Thans zal ook de dochter van den vorst, Dewi Sri, aan de initiatie-pijniging onderworpen worden, en de demon van deze ceremonie treedt hier, zooals zoo vaak, op in de gedaante van den vreemden vorst van Mendangkoemoewoeng, die haar ten huwelijk vraagt; hij is een vertegenwoordiger van de linkerphratrie, en de pop die hem in de wajang voorstelt is dan ook van het "geweldenaarstype»; ook zijn gezanten die het, naar den aard van hun meester, op verwaten toon gestelde huwelijksaanzoek overbrengen, zijn boeta's. Natuurlijk verzet Dewi Sri zich tegen het aanzoek, dat haar een gruwel moet zijn, daar het incestueus is; dan wordt zij verbannen, zoogenaamd omdat zij zich niet naar haar vader's wil wenscht te schikken, inderdaad omdat dit bij de wijding noodzakelijk is: ook zij trekt zich voor een tijd terug uit de samenleving, en ook zij gaat het woud in. De demon van de initiatie zet daar zijn werk natuurlijk voort: de boeta-gezanten achtervolgen haar onverpoosd en gunnen haar geen rust.

Tot hiertoe ontmoetten wij in het verhaal niets dat daaraan ook maar eenigermate het karakter van een agrarische mythe zou geven. Dewi Sri is eenvoudig de linkerphratrie, zooals haar jongere broeder de rechter-stamhelft voorstelt. Thans wordt door enkele trekken de nadruk gelegd op Dewi Sri's bijzondere affiniteit met den landbouw; en daarmee wordt meteen duidelijk waarom het hier, in afwijking van vele andere lakons, de linkerphratrie (Dewi Sri) is die het middelpunt van de handeling wordt, terwijl Sedana slechts een ondergeschikte rol speelt. Er is immers reden om aan te nemen, dat ons in de verdeeling van het oude Javaansche rijk van Kaṇdiawan onder diens vijf zonen, zooals wij die uit verschillende geschriften kennen, niet een historisch feit, doch een primitieve classificatie is overgeleverd, waarin met allerlei andere zaken ook de bedrijven gerangschikt waren; in al deze berichten nu wordt de landbouw gesteld als behoorend tot de linker-phratrie. ${ }^{2}$ ) — Dewi Sri komt nu op haar zwerftocht bij een echtpaar, Ki Boejoet Wangkěng en zijn vrouw, die het landbouwbedrijf uitoefenen; onverwachts verschijnt zij in het rijstblok en wordt door deze lieden, die als

1) Zie De Pandji-roman, 347.

ग) Vgl. De Pandji-roman, 334. 
landbouwers meer in het bijzonder haar onderdanen zijn, met grooten eerbied ontvangen. $\mathrm{Zij}$ kan slechts eenige oogenblikken blijven, maar in dien korten tijd toont zij toch nog even haar karakter van brengster van een speciaal cultuurbezit van het Javaansche volk door voorschriften te geven over het schoonmaken van het huis tegen den tijd van het bergen van den oogst. Juist als zij wil vertrekken, komen de gezanten van den b o e t a-vorst en eischen Dewi Sri's uitlevering; Boejoet Wangkeng weigert natuurlijk en bindt den strijd aan met de initiëerende reuzen. Hij delft het onderspit: als landbouwer ondergaat hij Dewi Sri's initiatie mede en wordt door de boeta's aan een $\mathrm{n}$ a $\mathrm{ngk}$ a-boom vastgebonden. - In den hemel ontstaat beroering door deze schokkende gebeurtenissen, en god Goeroe vraagt naar de oorzaak daarvan; Nerada antwoordt dat die ontstond doordat men Dewi Sri in het huwelijk wilde verbinden met den reuzenvorst van Mẹnḍangkoemoewoeng. Goeroe betuigt uitdrukkelijk zijn volle instemming met Dewi Sri's verzet - immers een dergelijke vereeniging ware bloedschendig - en hij draagt zelfs Nerada op haar den weg te wijzen naar haren «broeder» Sedana, op deze wijze wel te kennen gevend, dat deze de voor haar bestemde echtgenoot is.

Serdana houdt zich nog steeds met zijn volgelingen op in het woud van Mẹṇang-Agoeng; zijn dienaren trachten hem over te halen aan het zichzelf opgelegde lijden een einde te maken en naar het hof van zijn ouders terug te keeren. Maar hij weigert: hij wil pas terugkeeren als zijn zuster gehuwd is; ging hij eerder terug, dan zou dit maar uitstel in haar huwelijk veroorzaken! - Deze woorden zouden raadselachtig zijn, indien wij niet begrepen dat er mee bedoeld is, dat hij niet wil terugkeeren vóor zijn eigen initiatie en vooral die van zijn «zuster, geheel ten einde is gebracht, zoodat niets meer aan hun huwelijk met elkaar in den weg staat. De auteur van de redactie die wij vóór ons hebben, en die de beteekenis der figuren niet meer begreep en het paar Sri-Sedana voor zuster-en-broeder in den bloede moest houden, heeft alle moeite gedaan om den in het verhaal onvermijdelijken trek van dit sincest» weg te werken; echter te vergeefs, naar uit het vervolg blijkt.

Door Nerada op den goeden weg geholpen, komt Dewi Sri in Menḍang-Agoeng; zij valt haren broeder weenend om den hals, en deelt hem mee wat haar er toe gebracht heeft, het 
woud in te vluchten. Terwijl zij nog met elkander spreken, komt een afgezant van den boeta-vorst daar aan, en eischt opnieuw Dewi Sri op. Sědana moet dit weigeren: de verdediging van zijn zuster tegen den reus wordt nu voor hem zijn groote wijdingsproef; eerst na een hevig gevecht slaagt hij er in Kaladaroe, dien hij blijkbaar niet kan dooden, op de vlucht te drijven. - Men zou verwachten dat nu ook het huwelijk der beide hoofdpersonen zou rolgen, maar nog altijd is de tijd daarvoor niet gekomen; wèl voelt men dat de vereeniging nabij komt: voorloopig zullen zij te zamen een nederzetting stichten in het woud van Mendang-Agoeng, die een centrum van landbouw zal worden. Sexdana gaat op bevel van zijn zuster allerlei zaden van land- en tuinbouwgewassen halen bij Boejoet Sondong; deze sluit zich met zijn vrouw en onderhoorigen bij hem aan.

Ook aan het lijden van Boejoet Wangkěng, die nog altijd aan den $\mathrm{n}$ angka-boom vastgebonden zit en door zijn vrouw gevoerd wordt, ${ }^{1}$ ) komt thans een einde; Sedana verlost hem en voert het echtpaar en hun volgelingen mee naar het nieuwe rijk.

Nog een laatste beproeving hebben Dewi Sri en Raden Sexdana te doorstaan: Poelagra, de koning van Mẹ̣dangkoemoewoeng, ontsteekt in dolle woede, als hij van den mislukten tocht van zijn afgezanten hoort; hij geeft den moed nog niet op en nog eenmaal zal hij - zooals dat den vertegenwoordiger der linkerphratrie past - zich er tegen verzetten dat een vrouw uit zijne groep overgaat naar de andere stamhelft. Een hevige strijd ontstaat die, van wege de gelijkwaardigheid der partijen, onbeslist dreigt te blijven; alleen de hulp der goden brengt ten slotte aan Sedana de overwinning. - Thans behoort dan eindelijk, naar den eisch der mythe, het quasi-incestueuse huwelijk van Sri en Sedana voltrokken te worden; en kostelijk van Javaansche vaagheid en dubbelzinnigheid zijn de termen, waarmee in de lakon deze abloedschande, wordt weggewerkt en tegelijk toch weer als onvermijdelijk in uitzicht gesteld. Nerada roept hen samen vóór zich en doet, ten overstaan van alle goden, aan

1) Het is niet onwaarschijnlijk, dat wij ook in deze wijze, waarop aan Boejoet Wangkĕng zijn eten wordt toegediend, een mythische herinnering mogen zien aan iets, dat bij de initiatie werkelijk plaats had. A.W. Howitt (Native tribes of South-East Australia, 1904, blz. 563) deelt mee, dat bij den stam der Ngarigo de novieten gedurende de initiatie geen gekookt voedsel met de handen mogen aanraken; het wordt hun door hun verzorgers in den mond gestopt. 
beiden het voorstel om in het huwelijk te treden. Zij weigeren: zij zijn wèl bereid te huwen, doch Dewi Sri alleen met iemand die volkomen gelijkt op Sedana, en deze alleen met iemand die er uitziet als zijn zuster. God Nerada begrijpt den zin van van deze woorden uitmuntend, en zal hen nu zonder verwijl met eikaar in het huwelijk verbinden, doch daarvan schrikken zij - of beter: schrikt onze auteur - terug. Een uitweg wordt gevonden doordat Sedana naar een ander rijk - in sabrang verplaatst wordt; de verwantschapsband wordt gewelddadig verbroken. - Hiermee is het stuk ten einde; maar men voelt dat het onafwendbare slechts verschoven is; Sri en Sedana zullen tòch met elkaar in het huwelijk treden! ${ }^{1}$ )

$\mathrm{Nu}$ van uit het door ons ingenomen standpunt een bevredigende verklaring van de lakon Sri Sědana mogelijk bleek, spreekt het vanzelf dat we ook over de Měngoekoehan, die den indruk maakt van veel grooter ingewikkeldheid, naar dezelfde methode eenig licht pogen te doen opgaan. - De in de eerste plaats te beantwoorden vraag wordt natuurlijk weer: in welke verhouding staan god Goeroe, Kanekapoetra en de Retna doemilah, die later blijkt Ken Tisnawati te zijn, tot elkander? Ook in de lakon zelf liggen voldoende gegevens om dit vast te stellen, maar, ten einde zooveel mogelijk het verwijt van willekeurige interpretatie te ontgaan, schijnt 't mij verkieslijk om tevens in dat deel van de Manikmaja, dat aan het met den inhoud van onze lakon correspondeerende stuk voorafgaat, inlichting over de beteekenis van deze figuren te zoeken. Daar ${ }^{2}$ ) vinden wij, dat de schepping der Javaansche wereld verhaald wordt op de wijze, die vooruit te verwachten was: in den aanvang der tijden ontstaat uit den cinaos één wezen, de oppergod Wisesa; op dezen volgt de verdeeling in tweeën, en wel driemaal achtereen, of beter: driemaal worden in de twee-deeling twee zaken of wezens paarsgewijs tegenover elkaar gerangschikt: 1 hemel en aarde, 2 zon en maan, 3 de broeders Manik en Maja. Het verhaal loopt verder vrijwel uitsluitend over de beide laatstgenoemde figuren. Manik heet de ware opvolger van god Wisesa, hij heeft deel aan Wisesa's essentie, d.w.z. hij is de

1) In de lakon Mĕngoekoehan treden dan ook Wisnoe (d.i. Sědana) en Sri als man en vrouw op.

2) Winter, o.c. blz. 2 vlg. 
rechter-phratrie; hij is schoon van gestalte, en van schitterende kleur; een andere naam voor hem is Goeroe. Zijn broeder Maja, de linker-phratrie, is daarentegen zwart van kleur en van afzichtelijke gedaante; om hem eenigermate schadeloos te stellen, schenkt Wisesa hem een kostelijk juweel Rètna doemilah (d. i. de lichtende karbonkel), dat hij in zijn kuif plaatst ${ }^{1}$ ). Deze gegevens zijn toereikend om ook aan de hoofdpersonen uit onze lakon een vaste plaats in het Javaansche classificatie-systeem toe te wijzen, en ons vasten grond onder de voeten te geven voor een verdere verklaring van het drama:

Goeroe, die met de andere goden in zijn hemelsch paleis Martjoekoeṇda troont, is de voorvader van de rechter-phratrie; Kanekapoetra, die later blijkt de Retna doemilah bij zich te hebben, verbeeldt de linker-stamhelft. Op het oogenblik dat het spel begint, is de representant van de linkerphratrie bezig zichzelf te initiëeren; hij onderwerpt zich midden in zee aan zware kwellingen, dezelfde trouwens die in de werkelijkheid bij de wijdingsceremoniën steeds een voorname rol spelen, doch hier dan in mythische overdrijving: hij eet of drinkt niet, slaapt niet, en houdt zich volkomen stom. Maar tezelfdertijd wòrdt hij ook geïnitieerd, en de voor die taak van nature aangewezen officianten, de goden uit de andere phratrie, komen hem kwellen en trachten hem in zijn vrome oefeningen te storen. Te vergeefs echter; Kanekapoetra verdraagt onverschrokken de wijdingssmarten, en laat zich niet met zijn kwellers in. Dan begeeft Goeroe zich naar den licht-uitstralenden asceet, en in het twistgesprek dat nu volgt, komt op treftende wijze de rivaliteit der beide phratries tot uiting; Goeroe ontkent dat Kanekapoetra

1) Maja kan gevoegelijk den naam Batara Sĕmar dragen, zegt $\mathrm{Hjang}$ Wisesa in het verhaal. Het moet zeker verwondering wekken, dat de Sěmarfiguur, die we in de wajang altijd als panakaw an van een van de Pañdawa's ontmoeten en die dus bij de rechtsche partij behoort, hier plotseling op zoo duidelijke wijze links verschijnt, en nog wel voorgesteld wordt als de personificatie zelf van de linkerphratrie. De eenige mogelijke verklaring van deze schijnbare inconsequentie schijnt mij hierin gelegen, dat - zooals vroeger reeds werd opgemerkt - de figuren der panakawan's meer dan één zijde vertoonen en o.a. ook verbeelden de eigenlijke initiatoren, de zgn. verzorgers en leermeesters van den initiandus. Als zoodanig vergezellen zij natuurlijk den noviet en maken heel diens afzonderingstijd mee, maar zij behooren zoo althans schijnt in deze samenlevingen de oorspronkelijke toestand geweest te zijn - tot de andere phratrie. Vgl. Howitt, o.c. 512, 525, 564, $584,596,608,609,622$. 
aan hem gelijk zou zijn: het lot heeft nu eenmaal gewild dat hij (Goeroe) de heer des hemels is, hij is in waren zin de erfgenaam van Sang Hjang Wisesa, - hij is de oudste! $\mathrm{Nu}$ heeft inderdaad Goeroe in het eerste deel van zijn bewering gelijk, in het tweede echter niet: de rechter-stamhelft is wel de gunstige en meer voorname, maar de linkerphratrie geldt als de oudere. In triomfantelijken hoon wijst Kanekapoetra hem dan ook daarop en stelt zijn beter inzicht tegenover dat van Goeroe, en deze kan daar niets tegen inbrengen; bescheiden en op sussenden toon noemt hij Kanekapoetra zijn ouderen broeder ${ }^{1}$ ), erkent diens voorrang, en noodigt hem vriendelijk uit mee naar zijn hemel te gaan. Aan dit verzoek wordt voldaan. In zijn vastgesloten hand houdt Kanekapoetra de Rětna doemilah, die - zooals later ten duidelijkste blijkt - de vrouwefiguur is die de linkerphratrie voorstelt en dus bestemd is om met Goeroe in het huwelijk te treden. Deze laatste toont dan ook terstond zijn hevige begeerte om het juweel te bezitten; maar zijn wensch kan niet zonder meer in vervulling gaan, want vóór het huwelijk kan worden gesloten, moeten zoowel Retna doemilah als Goeroe zelf den inwijdingsritus doormaken. Deze initiatie wordt nu de eigenlijke inhoud van het drama.

Wanneer Kanekapoetra het lichtende juweel aan Goeroe toewerpt, kan deze dit niet opvangen of vasthouden, het kleinood komt hem nog niet toe; het verdwijnt en valt tot in het diepste der aarde, waar het wordt opgeslokt door den demon der initiatie, de monsterachtige slang Antaboga. De goden wederom onder patronaat van den vertegenwoordiger der andere phratrie, Kanekapoetra - gaan het zoeken, en na een langen zwerftocht komen zij eindelijk bij Antaboga. Hevig lijden hebben de goden te doorstaan in hun strijd met het monster, dat eindelijk erkent het juweel te bezitten, maar voor de uitlevering ervan den eisch stelt, dat men niet alleen het kostbare kleinood, maar ook hemzelf mee naar Goeroe's hemel zal voeren. Aan deze initiatieproef wordt in de lakon door de rechter-phratrie eigenlijk niet geheel naar den eisch voldaan, maar ten slotte verschijnt dan toch Antaboga met het doosje, waarin het juweel (d.i. het te initiëeren meisje) opgesloten is, vóór Batara

1) Goeroe wordt ook verder voortdurend door Kanekapoetra ijongere broeder" genoemd. 
Goeroe: de vrouw uit de linker-stamhelft is, ondanks den tegenstand van die groep, naar de andere phratrie overgebracht. Uit het doosje komt dan een djabang-baji estri (een klein meisje) te voorschijn, dat blijkens de moeite die het kost om het doosje te openen, reeds over geweldige magische kracht beschikt. Het is van verblindende schoonheid, ontvangt den naam Ken Tisnawati ${ }^{1}$ ), en groeit op in de bale Marakata, het - tegelijk met haar ontstane - paleis van de linker-phratrie. Wanneer zij den huwbaren leeftijd bereikt heeft, ontsteekt Goeroe in liefde voor haar en wil haar tot zijn gemalin maken; maar zij moet natuurlijk weigeren, en wel om het in deze verhalen altijd weer terugkeerende motief: zij zijn nog niet bevoegd met elkaar in contact te komen, daar hun beider initiatie nog niet is ten einde gebracht. Tot dit doel zal Goeroe thans aan drie moeilijk vervulbare wenschen van Tisnawati moeten voldoen; hij volbrengt de proef echter niet zelf, maar roept de medewerking in van den boozen god Kala en diens zoon Kalagoemarang; de laatste krijgt opdracht om de door Tisnawati verlangde voorwerpen te gaan zoeken ${ }^{2}$ ). Maar van zijn pogingen om hierin te slagen - d. i. dus van Goeroe's initiatie - hooren wij verder niets; ook in deze lakon gaat de aandacht weer bijna uitsluitend naar de linker-phratrie en naar de beproevingen die Dewi Sri (die, zooals wij later hooren, in wezen dezelfde is als Tisnawati) door te maken heeft. - Kalagoemarang verrast op zijn zwerftocht Dewi Sri, terwijl deze aan het baden is, en, wanneer zij vlucht, gaat hij haar achtervolgen. Zij zoekt bescherming bij god Wisnoe die - en deze trek komt in het verhaal te vroeg, daar immers dit huwelijk pas na afloop van de initiatie behoorde plaats te hebben - haar echtgenoot genoemd wordt. Op brutalen toon eischt Kalagoemarang haar op, en daar Dewi Sri er, zooals vanzelf spreekt, niet voor te vinden is zijn vrouw te worden, volgt zij Wisnoe's raad op om het

1) In een andere redactie van deze mythe krijgt de Rĕtna doemilah dezen naam pas later, n.l. na bet doorstaan van een volgende proef, wanneer zij den initiatie-dood gestorven is. Zie J. H. F. Sollewijn Gelpke, De rijstkultuur op Java; in Bijdragen Kon. Institıut, 3de reeks, IX (1874), 116.

2) Wanneer hij slaagt (dat wil dus zeggen: wanneer hij de opdracht om aan Goeroe's initiatie mee te werken, vervult) zal Goeroe hem aanstellen tot hofnar in den hemel en op aarde. Opnieuw zien we hier weer de identiteit van den initiator en den clown-achtigen panakawan. 
land te verlaten en de wijk te nemen naar Mendangkamoelan: daar zal zij zich incarneeren in Darma Nastiti, de gade van Měngoekoehan (welke vorst, zooals wij boven reeds opmerkten, als heerscher over de landbouwers in de Javaansche classificatie in de linker-phratrie is geplaatst); deze koning zelf wordt een verschijningsvorm van Wisnoe ${ }^{1}$ ). Op haar vlucht komt Dewi Sri in het woud, en hier wordt zij bijna door den haar altijd nog achtervolgenden demon van de initiatie gegrepen; Wisnoe redt haar nog juist door een wonderpijl af te schieten op den snoodaard, die valt en de gedaante krijgt van een varken.

Als Goeroe in den hemel verneemt dat zijn afgezant niet kan terugkeeren, dringt hij er opnieuw bij Tisnawati op aan dat zij zich met hem zal vereenigen. $\mathrm{Zij}$ kan dit niet doen, en wanneer hij geweld gebruikt, sterft zij in Goeroe's armen den initiatiedood; weldra zal zij in nieuwe gedaante en onder een nieuwen naam weer herleven. Haar lijk wordt n.l. door den bedroefden Goeroe aan Kanekapoetra toevertrouwd, die het moet begraven in Mengoekoehan's land, Meṇụangkamoelan. Hier wordt zij tot een ander bestaan gewekt; uit het lijden tot den dood toe van de moeder der linkerphratrie ontstaat het nieuwe leven en ontkiemen de kostelijke gewassen, waarvan de rijst de voornaamste is; uit haar hoofd groeit een kokospalm, uit het schaamdeel rijst, uit de handpalmen pisang, uit haar tanden mais. De rijst groeit welig op; Ki Boejoet en zijn gezellen die wij uit de zooeven behandelde lakon ${ }^{2}$ ) als panakawan's (d.i. verzorgers van den noviet) kennen, zijn ook hier belast met de bewaking en verzorging van het gewas.

Tegelijkertijd is daar ook een aren-palm ontkiemd en hoog opgegroeid. Hoe die is ontstaan, wordt in onze lakon niet vermeld, maar op te merken valt, dat hij onder de uit Tisnawati's lijk ontsproten planten $\mathrm{niet}$ voorkomt. In een andere redactie van de mythe ${ }^{3}$ ) is dit echter wèl het geval: hier groeit de rijst uit Tisnawati's navel, de aren-palm uit het schaamdeel. Ik aarzel niet deze laatste voorstelling voor een afwijking te

1) Dit laatste is duidelijk een mythologische fout. Vorst Mĕngoekoehan kan onmogelijk een verschijningsvorm van Wisnoe worden; zij behooren tot verschillende phratries. De onjuistheid vindt natuurlijk haar oorsprong hierin, dat in deze versie van de mythe het huwelijk van Dewi Sri en Wisnoe te vroeg gesteld is.

2) Zie boven blz. 322 .

3) Zie Sollewijn Gelpke, 1. e. 116. 
houden en te beschouwen als een mythologische fout. De arenpalm toch heeft in de Javaansche classificatie zeker niet behoord tot de linkergroep, hij kan niet anders zijn dan een verschijningsvorm van den voorouder der rechter-phratrie; want wij weten het van elders: de palmwijntappers zijn lieden van $\mathrm{rechts}^{\mathbf{1}}$ ). In de redactie van de Manikmaja wordt de juiste verhouding wel niet met duidelijke woorden meegedeeld, maar iets ervan schijnt er toch nog wel in door te klinken. Onmiddellijk nadat verteld is dat de uit Tisnawati's lijk ontsproten planten en ook de aren-palm welig opgegroeid zijn, wordt verder verhaald dat de god Pritandjala die de noord-oostelijke wereld bewaakt (dus tot de rechter-phratrie behoort) zich verwonderd afvraagt waar toch zijn beide broeders Kanekapoetra en Wisnoe gebleven zijn. Blijkbaar zijn de vertegenwoordigers der stamhelften verdwenen, niet maar één van hen, doch beiden. Hij verandert zich nu in een kleinen zwarten vogel (den emprit) en, aangelokt door den zoeten geur van de rijst, laat hij zich daarbij neer en snoept ervan; maar de bewakers van het gewas verjagen hem en hij verbergt zich dan tusschen de bloemstengels van den aren-palm. Deze boom wordt voor den vogel uit de rechterphratrie een vast verblijf, hij is als het ware zijn rechtmatige woonplaats, en telkens komt hij vandaar weer terug om het rijstgewas te kwellen. Om dit nu afdoend te beletten, verwoesten de landbouwers die schuilplaats door de aren-bloemkolven af te snijden; weldra komt dan het zoete vocht te voorschijn, het wordt in een bamboekoker opgevangen en aan Goeroe als voortbrengsel van zijn boom aangeboden. Wij gaan nu begrijpen wat het beteekent, dat niet alleen Kanekapoetra, maar ook Wisnoe verdwenen was. Uit het initiatie-lijden van den voorouder der rechter-phratrie ontstaat het kostbare suikersap, op gelijke wijze als Ken Tisnawati-Dewi Sri (of wil men: Kanekapoetra) in lijden en dood aan het menschdom de gaven van de rijst en andere landbouwgewassen bracht.

Nog altijd zijn Dewi Sri's beproevingen niet geheel ten einde. Ook in zijn nieuwe gedaante blijft Kalagoemarang haar achtervolgen, hij vertrapt het rijstgewas en wroet den grond om; Wisnoe helpt weliswaar en doodt hem, maar uit zijn bloed ontstaan tal van schadelijke dieren en parasieten en zijn ziel gaat

') Zie De Pandji-roman, 334 . 
over in de boosaardige kinderen van Poețoet Djantaka, wiens aard en beteekenis als belager van de rijst wij in de vorige lakon reeds hebben leeren kennen ${ }^{1}$ ). Deze «kinderen" zijn zonder uitzondering diersoorten, die in de natuur den te velde staanden oogst schade plegen toe te brengen; en dit lijden van het gewas is blijkaar door den dichter van de mythe opgevat als de smart, die de cultuurheros van de groep, waarin dit gewas gelocaliseerd was, heeft te doorstaan bij de vervulling van zijn (haar) aardsche zending ${ }^{2}$ ). Uit de rechter-phratrie, MendangAgoeng, komt wederom de hulp; het ongedierte wordt met magische middelen overwonnen en gedood, den stier en den buffel wordt het leven gelaten, doch zij worden getemd en tot huisdieren gemaakt. Ook de domesticatie van deze voor den landbouw zoo gewichtige dieren is, zij 't ook indirect, een gevolg van het lijden van de moeder der linker-stamhelft.

Ook deze mythe bleek dus, veelal tot in de details toe, toegankelijk voor de interpretatie die op de lakon Sri $\cdot$ Mahapoenggoeng paste; en ook hier vonden wij de hoofdtrekken van de Javaansche cosmogonie in zoo goed als regelmatig verband terug. Het feit, dat er onder de Javaansche drama's enkele zijn, die om hun inhoud bijzonder geschikt geacht worden om bij agrarische plechtigheden te worden opgevoerd, heeft thans niets bevreemdends meer, en geeft allerminst reden om die drama's te beschouwen als essentiëel afwijkend van de andere tooneelstukken. Men kan met reden in de boven besproken lakons bewerkingen van landbouw-mythen blijven zien; maar toch is 't niet dit wat deze verhalen volkomen typeert en voor ons begrijpelijk maakt. Verstaanbaar worden zij pas wanneer wij inzien, dat voor de Javanen de rijstgodin slechts een verbijzondering

1) Zie boven blz. 321 .

2) Het is evenwel volstrekt niet uitgesloten, dat ook voor deze bijzonderheden ten slotte op een classificatie kan worden teruggegaan, en dat werkelijk die dieren, die zich bij bepaalde gewassen plegen op te houden en zich daarmee voeden, door de Javanen gerekend werden tot dezelfde groep als waartoe die gewassen behooren. Herhaaldelijk is geconstateerd, dat "logica" van dezen aard in primitieve classificatie-systemen tot uiting komt. Vgl. bijv. dr. P. Wirz, Die Marindanim von Holländisch-Süd NeuGuinea, (1922) I Band, Teil II, 21, waar deze opmerkt dat bij de Marindanim bepaalde plantensoorten mèt de daarop levende "Schmarotzer und Parasiten" gerekend worden te behooren tot één „mythologisch-totemistischen verwantschapskring". 
is van de moeder van hun linker-stamhelft, en dat de agrarische kleur dezer verhalen alleen ontstond doordat op dit element in de classificatie een bijzondere nadruk is gelegd. In dezen zin kan men zeggen dat het agrarisch karakter van deze mythen secundair is; de lotgevallen van Dewi Sri en Wisnoe zijn ten slotte de gewone van het goddelijk voorouderpaar.

II.

De meening dat het nuttig kan zijn om bij een onderzoek naar den oorspronkelijken zin van het Javaansche drama ook eenige aandacht te schenken aan het oude $\mathrm{Ni}$ T Towong-spel, zal wel geen overmatige bevreemding wekken. Men kan geen beschrijving lezen van dit spel (dat thans nog hier en daar op Java en Madoera wordt aangetroffen, maar weldra geheel verdwenen zal zijn) of men bemerkt onmiddellijk, dat de auteur van het bericht getroffen is geweest door het eenigszins plechtig karakter van dit kindervermaak en door de ook nu nog niet volkomen verdwenen ritueele waarde die eraan wordt toegekend. Al weten wij ook niet wie Nini Towong eigenlijk is, en al is een tot in bijzonderheden gaande verklaring van het spel ook nog niet gegeven, wij hebben wèl de zekerheid, dat het eenmaal meer beteekende dan eenvoudig een kindervermaak. Prof. Hazeu's voorzichtig gestelde conclusie, dat "wat thans nog geschiedt als men "Nini Towong maakt» deels overblijfsel is, deels spelende nabootsing van een vroegere religieuse plechtigheid», en dat het oorspronkelijk was "een ceremonie van den echt JavaanschMaleisch-Polynesischen eeredienst, dateerend dus uit den tijd toen op Java het heidendom nog onbelemmerd heerschte, ${ }^{1}$ ), is algemeen aanvaard. Het denkbeeld om dit spel te gaan vergelijken met de wajang of het daarmee in eenig verband te brengen is, voorzoover ik weet, nooit gerezen of althans niet uitgesproken; maar het moet toch wel de aandacht getrokken hebben dat, toen prof. Hazeu in zijn boven geciteerd artikel een poging deed om het spel te verklaren en in de eerste plaats Nini Towong's identiteit vast te stellen, het hem bleek dat alleen de tooneelliteratuur hiervoor bruikbare gegevens opleverde. Ook in Javaansche geschriften van anderen aard komt Nini Towong wel voor, maar daar wordt alleen haar

1) Dr. G. A. J. Hazeu, Nini Towong; in Tijdschr. v.h. Bat. Gen. XLIII (1901), 100, 103.

Dl. 81. 
naam genoemd; in het tooneelstuk Pa ṇ o o pa pa daarentegen zag hij haar «zelf ten tooneele verschijnen en een zekere rol vervullen ${ }^{1}$ ).

In de volgende bladzijden wensch ik nu de aandacht te vestigen op eenige verschijnselen, die m.i. de conclusie wettigen dat de ritus, waarop dit spel teruggaat, in groote lijnen dezelfde is als die aan het Javaansche tooneel ten grondslag ligt. Daar het, tot recht verstand der zaak, noodig is, zich eerst de feiten nog eens helder voor den geest te brengen, en het hierbij niet alleen op de hoofdzaken maar ook op de kleinere bijzonderheden aankomt, meen ik niet beter te kunnen doen dan eenvoudig het belangrijkste deel van prof. Hazeu's beschrijving van het spel (d.i. dus zooals het te Jogja gespeeld wordt) bijna geheel met diens eigen woorden over te nemen. Van elders voorkomende, gewichtige afwijkingen doe ik in de noten verslag ${ }^{2}$ ).

De «Dolonan nini Towong" is een spel uitsluitend voor meisjes; jongens mogen er niet aan deelnemen ${ }^{3}$ ). Men *maakt

1) Ibidem, 74 .

2) Onze kennis van het spel is langen tijd slechts oppervlakkig geweest. Het oudst bekende bericht is van Raffles (die het echter aanduidt met den naam brindoeng) in zijn History of Java, vol. I, 345, ed. van 1817. Aan prof. Snouck Hurgronje danken wij een korte beschrijving ervan (in De Atjehers, II, 211), en het belang van deze mededeeling ligt vooral hierin, dat zij de naaste aanleiding is geweest voor prof. Hazeu om uitgebreide gegevens uit verschillende streken van Java te verzamelen en een nader onderzoek naar de beteekenis van het spel in te stellen. De resultaten hiervan zijn neergelegd in zijn opstel Nini Towong (in Tijdschr. Bat. Gen. XLIII, 36-107), dat het standaardartikel over dit onderwerp gebleven is. - Tevoren had E. L. M. Kühr (Schetsen nit Borneo's Westerafdeeling, in Bijdragen Kon. Inst. XLVI, 1896, blz. 86) een beknopte beschrijving gegeven van het spel, zooals hij 't had bijgewoond in Tĕmenggoeng (Kĕdoe) en het vergeleken met het permainan boeboe (spelletje met de fuik), dat hij aantrof bij de Maleisch-sprekende bevolking van de Westerafdeeling van Borneo. - De in prof. Hazeu's artikel verwerkte gegevens zijn later nog aangevuld, vooreerst door prof. B. Sehrieke, die het spel beschrijft, zooals het nog op Madoera in zwang is, en daar tevens eenige ethnologische besehouwingen aan vastknoopt (zie zijn artikel De Sintring of $\mathrm{Djiboet}$ op Bangkalan, in Notulen v.h. Bat. Gen. LVIII, 1920, 61 vlg.), en voorts door Inggris in zijne verhandeling Tjowongan in dedesa Gintoengan bij Gom bong ( $\mathrm{D}$ jaw a, I, 1921, 147 vlg.). - Ten slotte vermeld ik nog Stelling No. XV achter het acad. proefschrift van dr. H. Kraemer, waarin deze nadruk legt op een zijde van de Ni Towong-figuur, die prof. Hazeu opzettelijk buiten beschouwing had gelaten.

3) In Madioen zien de meisjes seherp toe dat geen jongen, als meisje vermomd, zich listig onder haar mengt en zóó aan het spel meedoet; want 
nini Towong” slechits op een der dagen van de lichte maan (tusschen den $10^{\text {den }}$ en den $15^{\text {den }}$ van de maand) ${ }^{1}$ ), en bij voorkeur op een malem $\mathrm{Djoemoengah,} \mathrm{of} \mathrm{nog} \mathrm{liever} \mathrm{op}$ een malð̌m Anggara-Kasih (= Sělasa-Kliwon). Alleen oude vrouwen, in 't bijzonder oude jonkvrouwen (prawan t o ewa) mogen of kunnen "anggawe nini Towong» ${ }^{2}$ ). Wanneer dus iemand - hetzij ter vervulling van een gelofte (wat vroeger vaak voorkwam), hetzij alleen ten genoege van zijn dochtertjes - 'nini Towong wenschte te maken», dan roept hij daartoe de hulp in van een of meer zulke oude vrouwen, aan wie hij tevens de geheele leiding van het feestje opdraagt. Deze gaan dadelijk in den voormiddag aan 't werk om - soms geholpen door eenige jonge meisjes uit de buurt - een pop te maken die Nini Towong zal voorstellen. De materialen zijn: een oude versleten waterschepper (siwoer of gajoer) die het hoofd, een dito vischfuik (woewoe of itjir) of ook wel een rijststoommand (koekoesan) die den romp, en eenige padistengels of een paar bezems die de armen voorstellen. Met behulp van kalk, beḍak en roet wordt aan 't geïmproviseerde hoofd een menschelijk aanzien gegeven, en 't lichaam wordt bekleed en opgesierd zooals men dat een bruid pleegt te doen. Ten slotte wordt de pop geplaatst op een wan van gevlochten bamboe, waaraan ze stevig wordt vastgebonden, zoodat men ze daaraan kan optillen en dragen. 't Is wenschelijk dat al de genoemde ingrediënten, maar vooral de waterschepper en de fuik of rijststoomer, expresselijk voor dit doel te voren ge s t ol e n worden ${ }^{3}$ ): als dat gebenrt, dan „lukt het niet". (Hazeu, o.c. 52). - Bij het d̦ ing di in g tjaspel op Bangkalan, dat veel op het $\mathrm{Ni}$ T ow ong-spel lijkt, maar zuiver kindervermaak geworden is, mogen zoowel jongens als meisjes meedoen; ook bij het djiboet-spel is dat het geval, maar de jongens en meisjes mogen nog geen teekenen van geslachtsrijpheid vertoonen, en zij moeten zich van te voren reinigen (Schrieke, o.c. 62, 65). - De zegslieden van Inggris deelden hem mee, dat in Bagĕlen het tjow ongan oorspronkelijk een meisjesspel was, maar thans komt het wel voor, dat jongens en ook ouderen meespelen (Inggris, l. c. 147).

1) In Bagělen tusschen den $10^{\text {den }}$ en den $17^{\text {den }}$ van de Javaansche maand (Inggris, 147).

2) In Madioen stelt men den eisch, dat een zoodanige vrouw loewas sari (over het climacteriunı) is, en men noemt haar da oekoen (Hazen, 51); in Wanasaba vast deze do oekoen drie dagen vóór zij als leidster van het spel optreedt (Hazeu, 54).

9) Dit is zeowat overal een vaste eisch. In Madioen wordt de benoodigde schepper of fuik liefst gestolen bij een weduwe (Hazeu, 51). 
de meisjes toch meenen dat alleen dàn hun "dolanan nini Towong» gelukken kan. En bijzonder in hun schik zijn ze, als ze bij hun diefstal op heeterdaad betrapt worden en de bestolene hen flink uitscheldt: dan zal zeker alles goed gaan.

Men zorgt dat de pop vóór zonsondergang gereedkomt, liefst reeds in den namiddag. Zoodra de zon onder is, nemen de oude vrouwen de pop in de armen en dragen haar, vergezeld van de jonge meisjes uit de buurt, in optocht naar een boemi bana bațari, d.i. een plek, die bewoond wordt door geesten en welke men daarom als "heilig» beschouwt. Zulke plaatsen zijn b.v. een sedert lang uitgedroogde put, een levende haag rondom de kěbon, vooral ook een plek die overschaduwd wordt door een heel ouden, breedgetakten boom, en natuurlijk ook een begraafplaats. Op den weg daarheen zingen of neuriën de meisjes : «Paḍa 'mboewang botjah badjang!» ${ }^{1}$ ) al maar door, steeds op denzelfden deun. Heeft men de heilige plek bereikt, dan wordt de pop daar neergezet; de oude vrouwen branden wierook en leggen een uit bloemen en vruchten bestaande sadjen (offer) erbij, terwijl een van haar shet woord doet», d.w.z. den op die plek vertoevenden geest (meestal bahoer ěksa genoemd) aanspreekt en zijn hulp en zegen inroept. "Moge door Uw zegen de widadari nini Towong afdalen in de pop, die ik hier voor haar heb neergezet; moge zij straks met ons meegaan naar de latar (erf) van N.N., en moge dan ons spelletje lukken». Zoo ongeveer spreekt zij.

Daarna keert men gezamenlijk naar huis terug, echter niet zonder iemand achter te laten ter bewaking van de pop: immers zij is zoo mooi uitgedost met kleeren en sieradiën, licht zou de een of andere snoodaard haar kunnen stelen! Intusschen verbreidt zich overal in den omtrek het gerucht dat er dien avond ten huize van N. N. een "dolanan nini Ṭowong» zal zijn; en weldra stroomen van alle kanten de meisjes toe en verzamelen zich op het erf van dezen N. N.

Is het ongeveer acht uur geworden, zoodat de maan reeds hoog aan den hemel staat, dan gaat men weer in optocht naar

1) D.i.: „Laten wij het kindje gaan wegwerpen!" - In Bagĕlen zegt degeen die de pop wegbrengt: "Akoe těka mrene arĕp nitipake botjah goeḍigèn marang kang rěksa panggonan iki!" d.i.: „Ik ben hierheen gekomen om een kind met schurft toe te vertrouwen aan den bewaker van deze plaats!' (Inggris, 148). 
de plek waar de pop was achtergelaten, terwijl de meisjes neuriën, op denzelfden eentonigen dreun als straks: "Padia moepoe botjah badjang!» 1$)$ Bij de bedoelde plaats gekomen, spreekt een der oude vrouwen: "Bok pěnganten! (o bruid!) Ik noodig U uit om mee te gaan naar gindschen "latar», om wat te spelen met de meisjes. Ik heb al een kind voor U gereed gezet.» Op het bewuste erf namelijk is - behalve eenige andere, straks te noemen zaken ook een gandik (een steenen cylinder, waarmee op een wrijfsteen 't een of ander, vooral medicijnen, wordt fijngewreven) klaargezet, waaraan men eenigszins de gedaante van een klein kind gegeven heeft, o.a. door hem in luiers te wikkelen: de aldus toegetakelde gaṇ $\mathrm{ik}$ noemt men ehet kind van nini Towong *.

Daarop neemt men de pop op, haar dragend bij de wan waarop $z e$ is vastgebonden, en brengt haar naar het voor deze gelegenheid helder schoongeveegde erf van den reeds genoemden N.N. Hierbij heeft men er wel op te letten, dat men een anderen weg kiest dan dien, langs welken te voren de pop naar de heilige plaats gebracht was. Volgens algemeen gevoelen is de pop nu "zwaar, omdat ni Towong er reeds in is afgedaald.

Op het erf gekomen, zet men nini Towong neer op een nieuwe mat, met het gezicht naar 't Oosten in de richting van de maan. Vier of vijf vrouwen zitten rondom haar en houden de wan vast, waarop de pop is vastgebonden. Van tijd tot tijd houdt een van haar een gereedstaand potje met brandende wierook onder de wan, zoodat ni Towong di-oekoepi (bewierookt wordt). Vlak vóór haar is gereedgezet: een aarden pot (pěnga ron), waarin water en bloemen, en soms ook nog wel een klein stukje spiegelglas (katja) is gestoken; een spiegeltje (pangilon); een potje met w ědak; de boven besproken, in luiers gewikkelde ga ṇ ḍik en een olielampje ( $\mathrm{tj}$ čloe pak). Bovendien moet er voortdurend wierook worden gebrand: men heeft vooral te zorgen dat deze niet uitdooft. De meisjes plaatsen zich achter en aan weerszijden - alleen vlak vóór nini Ṭowong mag zich niemand bevinden, "want zij moet steeds de maan kunnen zien» - en roepen haar 't welkom toe met de woorden: "Bok lara (of:

1) D.i.: „Laten wij het kindje gaan oprapen!" - In Bagĕlen prevelt degeen die de pop terughaalt, het volgende formulier: ${ }_{n} \mathrm{Ak}$ oe $\mathrm{ngikoeti}$ botjah goeḍigĕn arĕp dak-kon djogedan", d.i.: "Ik raap een kind met schurft op om het te laten dansen". (Inggris, 148). 
pěnganten) sira bageja!» of "Bageja, bageja, bok lara lagi těka!»

$\mathrm{Nu}$ kan het feest beginnen. Terwijl de oude vrouwen de wan steeds vasthouden, gaan de meisjes allerlei liedjes zingen, slechts begeleid door het slaan met een ilir (vuuraanblazer) op een boejoeng (groote aarden waterkruik). Onderwijl noodigt men nini Towong herhaaldelijk uit zich te spiegelen in het water van de perngaron of in het gereedgezette spiegeltje, dat men haar voorhoudt. Eindelijk, als het gezang lang geduurd heeft, krijgen de oude vrouwen, die de wan vasthouden, de gewaarwording dat er leven komt in de pop, dat zij op 't punt is «bezield, te worden. Zoodra men dit bemerkt, houdt 't gezang op, en de meisjes manen nu de widadari aan om toch voorzichtig te zijn in haar bewegingen, opdat zij zich niet stoote. Want nini Towong begint nu steeds snellere bewegingen te maken, weldra springt zij op en neer en de vrouwen hebben moeite haar vast te houden. En door een nieuw wijsje vuren de meisjes haar nog verder aan, en zij danst en springt àl lustiger.

Dan begint de eigenlijke pret. Een der meisjes b.v. neemt de gaṇịk, "het kind van ni Ṭowong", stilletjes weg, verstopt ze ergens en zegt dan: "Ni Towong, ik heb je kindje weggehaald!, Eindelijk wordt het kindje weergevonden en laat men het aan ni Towong zien met de woorden: "Kijk, je kindje is terecht!» Ook houdt men haar wel de gaṇdik voor en zegt: «Kijk, je kindje huilt!, waarop een der meisjes het in haar armen neemt en het quasi tracht te sussen door een der bekende slaapdeuntjes. Een vaste aardigheid is het ook, dat de meisjes ni T Towong plagen en bespotten; deze wordt boos en jaagt de meisjes achterna, nu eens de een, dan weer de ander, zonder er ooit een te krijgen; het is erg "rame !

Daarna is er nog een andere aardigheid. Men gelooft, om zoo te zeggen bij overlevering, nog steeds dat ni Ṭowong meer weet dan de menschen. En zoo is het nog altijd gebruik, dat men haar allerlei vragen doet. Is er iemand ziek, dan zal zij door een hoofdknik in een bepaalde richting het boomblad of de plant aanwijzen, die men als geneesmiddel moet aanwenden. Op dezelfde wijze duidt zij ook aan waar een verloren voorwerp te vinden is, of wijst den dief aan die het gestolen heeft. Ja op verlangen geeft zij zelfs aan het meisje te kennen wie haar toekomstige bruidegom zal zijn, of licht de bruid in over het 
aantal kinderen dat haar is toegedacht ${ }^{1}$ ). Dit alles verschaft aan de meisjes en aan de talrijke toeschouwers een groote pret, die tot laat in den nacht, tot 12 of 1 uur dikwijls, voortduurt. Eindelijk zegt een der oude vrouwen: $* \mathrm{Nu}$ is 't genoeg. Gaat nu uiteen., En daarmee is het spel uit. De pop, die nini Towong voorstelde, wordt òf op 't dak van 't huis geworpen, ò ook wel naar de vroeger genoemde heilige plaats teruggebracht, opdat - zooals een der oude vrouwen er uitdrukkelijk bij zegt - de widadari die er in afgedaald was weer naar haar gewone verblijfplaats zal kunnen terugkeeren. Soms haalt men later den waterschepper en de vischfuik of rijststoomer van de plaats waar de pop was neergeworpen weg, om ze nog eens voor hetzelfde doel te kunnen gebruiken.

Voor het door prof. Hazeu bij zijn poging tot verklaring van het spel geleverde betoog moge ik naar het artikel zelf verwijzen; hier vermeld ik slechts in het kort zijne conclusie, dat - al kan op het eerste gezicht de omstandigheid dat zij een widada ri genoemd wordt, het vermoeden doen ontstaan, dat Nini Towong van vreemden, Voor-Indischen oorsprong is - men om allerlei andere redenen wel moet aannemen dat zij een echt-Javaansche figuur is. $\mathrm{Zij}$ is <klaarblijkelijk een van de tallooze geesten van 't oude Javaansche (of Maleisch-Polynesische) spiritisme, en wordt vereerd als een goede fee, een beschermgeest vooral van huis en erf, een altijd vertrouwde vraagbaak en bereidwillige hulp in de kleine moeilijkheden van 't huiselijk leven.${ }^{2}$ ) Haar wenschte men telkens te raadplegen, en om dit te kunnen doen was het - volgens de voorstellingen van den tijd, waaruit de plechtigheid dateert - noodig om door daartoe geëigende middelen die fee te lokken in een met de noodige voorzorgen door een priesteres of toovenares vervaardigd beeld. Dan kon men zich met haar in contact stellen; men onthaalde haar op lekkere spijzen en andere aangename zaken, en daarna droeg men zijn

1) Ni Towong is zeer veelzijdig: zij heet beschermvrouw van de keuken, van de latar, van de kali en van de begraafplaats. In Bagělen speelt men vooral de "tjowongan", wanneer het lang achtereen bijzonder droog geweest is; men hoopt dan door haar bemiddeling regen te krijgen (Hazeu, 55; Inggris, 147). Ook wordt hier wel haar bescherming ingeroepen voor de kinderen, wanneer die bij invallende duisternis op het erf spelen.

2) Hazeu, o.c. 81 . 
wenschen voor: men vroeg hulp, raad, bescherming. En als zij het verzoek had ingewilligd, dan gaf men haar weer gelegenheid, naar haar veronderstelde verblijfplaats terug te keeren; het beeld dat dan weer contzield» was, had geen waarde meer: het werd weggeworpen of vernield ${ }^{1}$ ).

Prof. Hazeu heeft niet nagelaten te doen uitkomen, dat de door hem in zijn artikel neergelegde resultaten een voorloopig karakter dragen, of liever, dat door zijn betoog de beteekenis van het spel en het mythologisch karakter der voorgestelde personen nog slechts in zeer algemeene trekken zijn aangeduid. Dat in dit kindervermaak een oude, echt-Indonesische ritus voortleeft, staat door zijne beschouwingen voor goed vast; wat echter de bijzondere zin van elk onderdeel dezer plechtige handeling geweest is, is nog geenszins uitgemaakt. Vele van de overal voorkomende eigenaardigheden werden òf opzettelijk onbesproken gelaten òf konden alleen onder groot voorbehoud worden verklaard; en terstond reeds de vraag, wie ni Towong is, leek hem voor een scherpe beantwoording niet vatbaar zoolang niet nadere gegevens daartoe de mogelijkheid zouden openen.

Ik meen nu, dat ten minste een vast aanknoopingspunt voor de beantwoording van deze vraag gegeven is in Hazeu's belangrijke en ongetwijfeld juiste opmerking, dat $\mathrm{Nini}$ Towong (zooals zij voorkomt in de lakon Paṇdoe papa) in blijkbaar dezelfde relatie staat tot haar daar genoemde vier gezellinnen, de meer deftige widadari's, als in de wajang de panakawan's zich verhouden tot de Pandawa's, Ardjoena en zijn broeders ${ }^{2}$ ). - In mijn proefschrift heb ik mij beijverd om eenig licht te doen vallen op deze verhouding en in 't algemeen op de eigenaardige positie die de interessante figuren dezer panakawan's steeds in het Javaansche drama innemen, en een poging gedaan om voor de oogenschijnlijk zoo sterk contrasteerende karaktertrekken van deze «dienaren» een verklaring uit één gezichtspunt te vinden ${ }^{3}$ ). Ik uitte toen de meening dat de stamheros, de edele mannefiguur uit de wajang, met zijn vast bij hem behoorend stel van drie of vier bedienden eensdeels oorspronkelijk niets anders is dan hijzelf in vier- of vijfdeeling: de stamheros vormt met zijn ge-

1) Hazeu, o.c. 100.

2) Hazeu, o.c. 77 .

$\left.{ }^{3}\right)$ De Pandji-roman, 359. 
zellen een vaste eenheid, zijn dienaren maken den geleidelijken voortgang van zijn initiatie automatisch mee en gelden in zekeren zin als zijn gelijken; maar evenals in de realiteit de noviet gedurende zijn proeftijd in het woud voortdurend vergezeld wordt door eenige ouderen die zijn verzorgers zijn en zijn meerderen in kennis, en die hem die kennis nu eens in ernstige onderrichting, dan weer gedurende den ritus in lachwekkende vertooningen meedeelen, moest ook de mythische voorvader (zoodra hij niet werd voorgesteld als de ceremoniën alleen in eigen persoon aan zichzelf - voltrekkend) omgeven zijn door eenige volgelingen die tegenover zijn hoogen goddelijken staat vanzelf eenigszins zijn minderen zijn, maar door hun leeftijd en hoogere wijsheid toch weer zijn meerderen, en tevens, in verband met hun houding in den ritus, clowneske figuren. Hoe men nu ook over deze, uiteraard eenigermate subjectieve, interpretatie denke, in ieder geval zal wel door ieder, die geen vreemdeling is in de Javaansche tooneelletterkunde, toegegeven worden dat telkens weer een zekere identiteit aan den dag komt van de panakawan's en hun meester. En hetzelfde geldt van de vrouwelijke pendanten van de panakawan's, de paranjaï; op volkomen overeenkomstige wijze zijn deze de doubletten van hun meesteres, de edele vrouwefiguur van het wajangtooneel ${ }^{1}$ ). - Hieruit moet dus nu, bij het vraagstuk dat ons bezighoudt, vanzelf volgen dat Nini Towong, die in de lakon Paṇdoe papa als paranjaï optreedt en in de Soedamala ${ }^{2}$ ) ook volkomen naar den eisch aan den panakawan Sermar tot vrouw wordt gegeven, in wezen de vrouwelijke voorouder is van het Javaansche volk, de personificatie van de linkerphratrie, zij 't dan wellicht ook niet in haar edelste, meest gecultiveerde gedaante ${ }^{3}$ ). Toetst men nu deze stelling - met wat daarin ligt opgesloten van een op een stam-organisatie teruggaand classificatie-systeem - aan de boven gegeven gedetailleerde beschrijving van het spel, dan wordt die, naar het

1) Brandes zegt van de panakawan's en inja's. „Hunne handelingen, hun heele doen en laten zijn een reflex van hetgeen de held en de heldin verrichten, die ze vergezellen". (Tjandi $\mathrm{Dj}$ ag o, 1904, blz. 41).

2). Zang IV, strophe 31--45. Zie Dr. P. V. van Stein Callenfels, De Sudamala in de Hindu-Java ansche kunst (Diss. Leiden 1924; niet in druk verschenen).

3) In Tjiandjoer heet $\mathrm{Ni}$ Ṭowong wel: Nini Boejoet, d.i. „Vrouwe Voorouder". (Zie Hazeu, 55). 
mij voorkomt, volkomen bevestigd, en tevens gaat er een verrassend licht op over ongeveer alle bijzonderheden van de ceremonie.

Het spel mag alleen gespeeld worden bij wassende-tot-volle maan; dan wordt overdag de pop, waarin nini Towong zal afdalen, gereedgemaakt en in den avond - doch eerst wanneer de zon onder is en de maan aan den hemel staat - wordt zij naar de heilige plek gevoerd; daar wordt zij opgesteld met het gezicht naar de maan toe; en ook later (wanneer de pop is teruggebracht naar het erf van den vader die het initiatief voor het spel nam) wordt zij met het gezicht in die richting geplaatst en geen van de meisjes mag gaan staan tusschen de pop en de maan in: $\mathrm{Ni}$ Towong moet voortdurend de maan kunnen zien. - Prof. Hazeu heeft aan deze betrekking van het $\mathrm{Ni}$ Towong-spel tot de maan voorloopig niet veel gewicht willen hechten, "omdat uit den aard der zaak alleen de lichte avonden voor spelen en feesten geschikt zijn >; maar heel de wijze waarop die betrekking hier tot uiting komt, het dwingende van de voorschriften, en vooral ook het voor de meisjes geldende verbod om het op het gelaat der pop vallende schijnsel van de maan te ondervangen, geven zoo goed als zekerheid dat deze bijzonderheid een diepere beteekenis heeft. En - nu wij langs anderen weg reeds een sterk vermoeden omtrent $\mathrm{Ni}$ T Towong's identiteit kregen - behoeft naar deze diepere beteekenis niet ver te worden gezocht. Wij weten van elders, dat en op welke wijze ook de schijngestalten der maan waren opgenomen in het Javaansche rangschikkingsstelsel: de wassende-tot-volle maan behoorend tot de linkerphratrie, de afnemende maan tot de rechter-stamhelft ${ }^{1}$ ). Het innige verband van het geheele spel en vooral van de pop, die nini Towong voorstelt, met de lichte maan, heeft dus niets raadselachtigs; het vloeit op volkomen logische wijze voort uit het classificatie-systeem, en de boven neergeschreven hypothese omtrent $\mathrm{Ni}$ Towong's beteekenis is reeds door dezen éénen trek tot zekerheid geworden; zij is de personificatie van de linkerphratrie, en wel in haar bijzondere gedaante van (wassende-tot-volle-) maangodin.

Tot de wonderlijkste en het moeilijkst te verklaren eigenaardigheden van het spel behoort zeker dat nini Towong in den loop van de ceremonie telkens met een anderen naam wordt

1) Vgl. De Pandji-roman, 219. 
aangeduid en ons als 't ware telkens in een andere hoedanigheid wordt voorgesteld. Wanneer de pop op de latar gereedgemaakt is en door de meisjes en de oude vrouw, die als leidster optreedt, wordt weggebracht naar de heilige plek om daar te worden "bezield», heet zij een botjah badjang, d.i. ceen klein kind dat nog het haar heeft, waarmee het ter wereld is gekomen» of seen weliswaar goed geproportioneerd, maar dwergachtig gebleven wezen ${ }^{1}$ ); en volgens het wijsje, dat de meisjes bij deze handeling neuriën, wordt dit kindje dan 'weggeworpen». In Bagelen wordt in dit stadium van het spel de pop eveneens een «kindje, genoemd, maar men zegt ervan dat het aan schurftziekte lijdt en dat men het komt toevertrouwen aan den bewaker van de heilige plaats. Later - wanneer naar algemeen gevoelen de pop "zwaar is geworden omdat nini Towong erin is afgedaald - wordt zij toegesproken als «bruid» (bok pěnganten); als zoodanig is zij te voren dan ook al opgesierd; ook op de la t a r wordt zij verwelkomd als "maagd" (bok la ra) of "bruid", en in de liedjes heet zij de "nieuwe bruid»; - en toch wordt kort daarvóór, als een aansporing om toch gewillig mee te gaan naar de latar, tot haar gezegd dat "haar kind" (de gaṇ dik) al klaar staat! In Wanasaba eindelijk wordt nini Towong genoemd e ṇ ḍang ${ }^{2}$ ), d.i. «non, ascete»; en in Batavia wordt in een der liedjes die gedurende het spel gezongen worden, van haar gesproken als van «een nonah, die een schip met den geliefde verwacht, $!^{3}$ )

Zonderling en moeilijk met elkaar vereenigbaar als al deze trekken zeker moeten schijnen, vinden zij, meen ik, onmiddellijk en zonder moeite een volkomen verklaring in de opvatting, dat wij in Nini Towong te zien hebben de voorouder van de linkerphratrie, die vóór haar huwelijk met den vertegenwoordiger der rechter-stamhelft de wijdingsceremoniën heeft door te maken en nu geleidelijk de transformaties, die daaraan verbonden zijn, ondergaat. Bij den aanvang van het spel is zij een ongeinitie e rde ${ }^{4}$ ); de pop heet dan ook een klein meisje of een dwergje

1) Of: „een kind, dat nog de melktanden heeft”. Van der Tuuk vertaalt pabadjangan met: kerkhof voor kinderen, die nog niet van tanden hebben gewisseld. (Zie Pararato n, ed. Brandes-Krom, 47, nt. 7).

2) Hazeu, 54.

3) Hazeu, 56, nt. 2.

4) Hiermee krijgt het ook zijn volle beteekenis, dat het spel alleen gespeeld wordt door jonge meisjes, die nog niet puber zijn. Dat jongens niet mee 
dat naar buiten, naar het wo ud (boe mi ba na) wordt gedragen en wordt «weggeworpen ( d i-boewang). Dit laatste woord zou vreemd zijn en zeker niet in overeenstemming met de zorg, waarmee de pop wordt vervaardigd en uitgedost en op de heilige plek bewaakt, indien 't niet terstond duidelijk was, dat wij hier di-boewang moeten opvatten in den zin van kverbannen, te vondeling gelegd". Zooals wij dat in de lakons ${ }^{1}$ ) en wajangverhalen voortdurend zien, en zooals dat trouwens zuiver uit de werkelijkheid is overgenomen, wordt $\mathrm{Ni}$ Towong hier voor een zekeren tijd uit de samenleving verwijderd om in de wildernis buiten den stam (hier dus buiten de latar) als as cete (e n d ang) te gaan leven en den inwijdingsritus door te maken ${ }^{2}$ ). Gedurende dien afzonderingstijd verkeert de noviet in groot gevaar, en de pop wordt daar dan ook door iemand - die dus als haar patronus optreedt - bewaakt; en later wordt zij (alweer ter misleiding van den demon der initiatie en ter voorkoming van het verzet der linkerphratrie) langs een anderen weg naar de latar teruggebracht. In deze opvatting past ook volkomen de boven gerelateerde uitdrukking die in Bagělen gebruikt wordt: inderdaad geldt de noviet als een $\mathrm{zieke}$, hij verkeert in een ernstigen taboe-toestand; en dat hier van $\mathrm{schurft}$ gesproken wordt, mag men waarschijnlijk toeschrijven aan het feit dat nini Towong zoo geprononceerd de trekken van de volle-maangodin

mogen doen, komt natuurlijk doordat het wederom bijna uitsluitend de vrouwelijke voorouder is, die ten tooneele verschijnt; ook de mannelijke voorouder speelt wel een rol, maar die is, zooals wij zien zullen, van ondergeschikten aard.

1) Zie bijv. boven, blz. 333 .

2) In De Pandji-roman (blz. 303 vlg.) heb ik reeds in het kort trachten aan te wijzen, van welken aard de motieven zijn die in de levensbeschrijving van Ken Arok, den stichter van het vorstenhuis van Toemapĕl, zooals men die vindt in de inleiding van den Pararaton, zijn verwerkt. In dit verband vestig ik er de aandacht op, dat ook het jonge kind Ken Arok door zijn moeder wordt te vondeling gelegd; en het is aardig om naast het refreintje, dat de meisjes in ons spel zingen bij het wegbrengen van de zoo nauw met de maan in verband staande - pop (pada mboewang botjah badjang) de woorden te plaatsen waarmee de "te-vondeling-legging" van den licht verspreidenden Ken Arok in den Pararaton meegedeeld wordt (binuñcal ing pabajangan), en de wezenlijke identiteit van beide uitdrukkingen op te merken. Naar den zin behooren wij de laatste woorden te vertalen met: (Ken Arok) ${ }_{n}$ werd naar het initiatie-terrein gebracht". - Voor de beteekenis van den mythischen trek, dat Ken Arok door een di f f wordt gevonden en als kind aangenomen, zie men hieronder blz. 358 . 
vertoont. Zeker wordt wel op dit laatste gedoeld, wanneer men haar te Batavia een nonah noemt, die een schip met den gegeliefde (d.i. de afnemende maan, die het beeld vertoont van een boot) verwacht ${ }^{1}$ ). - Is deze phase van den ritus afgeloopen en is het gelukt de pop veilig en wel over te brengen naar de latar, dan is 't niet meer dan gepast dat zij een nieuwen naam krijgt en nu als ebruid, wordt aangesproken: zij is de geïnitiëerde linker-phratrie, van klein meisje is zij geworden tot volwassen "maagd" en tot de sbruid" bij uitnemendheid, die nu in het huwelijk zal gaan treden met den voorvader van de rechterstamhelft. Dit laatste moet men inderdaad thans verwachten, maar deze verwachting schijnt niet in vervulling te gaan; immers van een echtgenoot van nini Towong wordt verder niet gesproken, zij vindt in het spel slechts de ga ṇ $i k$, "haar kind». Nu zou - dit is bekend - op zichzelf deze verhouding van moeder en zoon, in de mythe die wij hier vóór ons meenen te hebben, geen beletsel zijn voor een huwelijk; integendeel, een "incestueuse» relatie is precies wat wij denken te vinden; en volkomen naar den eisch is het dat de linkergroep weer tegenover de rechterstamheift als de oudere optreedt. Dat nu hier nini Ṭowong de moeder van de ga ṇ dik genoemd wordt, kàn weer een uitvloeisel zijn van het sterk maan-mythologisch karakter dat de ceremonie heeft: in elken maan-omloop toch komt de afnemende maan uit de volle maan voort en moet dus wel als haar zoon gelden. Maar de eigenlijke zin van dezen trek schijnt mij toe toch dieper te liggen, en het komt mij voor dat de nadruk niet gelegd moet worden op de omstandigheid dat de gaṇik nini Towong's kind is, maar hierop dat hij een kind genoemd wordt. Ook de voorvader van de rechterphratrie is nl. in dit stadium van het spel nog maar een onvolmaakt wezen, een kindje, dat nu door het gebruikelijke ritueel tot volledigen wasdom zal moeten worden gebracht. Want ook de ga ṇ dik wordt geïnitiëerd: ook deze pop verdwijnt, ze wordt door de spelers stilletjes weggenomen en verstopt, en evenals wij in de lakon Mahapoenggoeng Dewi Sri haar jongeren broeder Sedana zagen gaan zoeken in het woud, en evenals in de wajangverhalen Sekar Tadji (of hoe zij dan ook in ieder bijzonder geval heeten moge) in eindelooze tochten

1) Vgl. De Pandji-roman, 198 vlg. 
haar geliefden «broeder» Inoe tracht te vinden - zoo zoekt nini Towong hier haar "zoon" die eigenlijk haar "bruidegom, is. Met dezen laatsten naam noemt, zooals wij zagen, de mythe hem weliswaar nergens, maar zie ik wel, dan is in de ritueele gebaren het oorspronkelijk karakter van dit deel van de ceremonie nog op aardige wijze bewaard gebleven. Zoodra n.l. nini Towong op het erf is aangekomen, wordt zij op een nieuwe mat neergezet en de gaṇdik wordt bij haar gelegd; beiden worden vervolgens bewierookt en bij hen worden geplaatst: een aarden pot, waarin water en bloemen, en waarin soms ook nog een klein stukje spiegelglas is gestoken; een spiegeltje; een potje met blanketsel en een olielampje; soms ook (in Bangkalan) een haarkam, enz. Deze voorwerpen nu komen op merkwaardige wijze overeen met wat men wel de vaste paraphernalia van het Javaansche $\mathrm{h} u$ welijk zou kunnen noemen. De dingen zelf toch en heel deze ritueele ensceneering moeten onmiddellijk doen denken aan het ook nu op Java nog in eere gehouden gebruik dat, op den avond vóór het huwelijk, bruid en bruidegom eenigen tijd naast elkaar in staatsie gaan zitten op het heiligste plekje van het Javaansche huis, vóór de kobongan; de binnenruimte daarvan wordt geheel ingenomen door een soort van staatsiebed, en daar zijn aanwezig allerlei toiletartikelen (een spiegeltje, een haarkam, welriekende olie), een ouderwetsche waterkom en een aarden of koperen pot, met offers aan de voorouders; op bepaalde dagen brandt men er ook wierook. Ook bij deze ceremonie worden wel twee poppen gebruikt; soms bevinden zich n.l. in de kobongan ook twee beschilderde houten beelden van een man en een vrouw in oudjavaansch kostuum, en men kan met grond vermoeden dat deze de beide voorouders voorstellen op het oogenblik van hun huwelijk. Want daarop duidt toch zeker - in verband met het ritueele gebruik dat ervan gemaakt wordt - de naam van deze beelden: loro blonjo, d.i. shet rijkelijk gezalfde paar ». ${ }^{1}$ )

Een bevestiging van al het tot hiertoe gezegde vinden we nu in den trek, dat de materialen, waaruit de pop, die nini Towong zal voorstellen, vervaardigd wordt, gestolen moeten worden. Ook in dezen eigenaardigen spelregel heeft prof. Hazeu

1) Vgl. Hazeu, De kobongan in het Javaansche huis, in: Verslag van het eerste Congres van het Oostersch Genootschap. in Nederland (1921), 39. 
geen diepere beteekenis gezocht; hij meende de reden ervoor te vinden in den begrijpelijken wensch der spelers om materiaal in handen te krijgen dat al vroeger, liefst al generatie's lang, als zoodanig had dienst gedaan en waarvan men dus onderstellen kon dat het voor de ceremonie geschikt was. Zulke kostbare stukken wilde echter niemand gaarne afstaan; "wie dus, nini Towong willende "maken», zelf niet in het bezit is van zulke gewenschte oude materialen, kan ze alleen verkrijgen door stilletjes wegnemen. En als nu de bestolene, den diefstal bemerkt hebbende, boos wordt en gaat schelden, dan bewijst dit aan haar die ze wegnam, dat zij werkelijk het gewenschte materiaal is machtig geworden. Op deze wijze kan van lieverlede het stelen van de siwoer etc. adat zijn geworden en zijn gebleven, ook nadat de bedoeling vergeten was» ${ }^{1}$ ). - Ten gunste van deze opvatting pleit, dat zij in overeenstemming is met wat de Javanen er - thans - van zeggen: vroeger (zoo vertelde men aan prof. Hazeu) placht men deze zaken alleen dàn te stelen, als men zelf geen aan de eischen voldoende materialen bezat ${ }^{2}$ ). Maar het is niet noodig er hier nog eens opnieuw aan te herinneren dat aan dergelijke, van inlandsche zijde gegeven, verklaringen van zeer oude gebruiken, zoo zij niet op andere wijze worden bevestigd, geen groote waarde kan worden toegekend. Meestal bewijzen ze alleen dat ook de inlander zelf de ware beteekenis van die gebruiken niet meer kent. In het geval dat ons bezighoudt maakt de verklaring al terstond een zeer rationalistischen indruk; een 7.00 uitermate practische overweging schijnt reeds a priori weinig geschikt om het dwingende en overal geldende van het voorschrift te motiveeren. Ook past zij, zooals prof. Hazeu zelf toegeeft, maar gebrekkig op de eigenaardigheid in kwestie: in de gegeven verklaring ligt immers geïmpliceerd dat men alleen materialen zou stelen, die reeds vroeger voor een dergelijke ceremonie gediend hebben. Dit laatste nu wordt nergens geëischt, en zou trouwens niet mogelijk zijn, want na het spel worden de materialen althans voor een deel vernietigd; het voorschrift luidt dan ook slechts zoo algemeen mogelijk, dat men de voorwerpen zal stelen. Geheel raadselachtig blijft verder in deze opvatting ook de hoogst eigenaardige manier waarop deze diefstallen ge-

1) Hazeu, 84 .

2) Hazeu, 41, nt. 1 . 
pleegd moeten worden: diefstal in den gewonen zin kan men het niet noemen, want het element van heimelijkheid is eigenlijk totaal afwezig; het is juist wenschelijk dat het wegnemen gezien wordt en dat er ruzie ontstaat en gescholden wordt. Dit laatste heet zelfs een onmisbare factor om het spel te doen gelukken: hoe meer er gescholden wordt, des te beter. - Maar er is nog een andere en, naar het mij voorkomt, afdoende reden waarom de gegeven verklaring in geen geval kan worden aanvaard: in het spel worden n.l. twee poppen gebruikt: 1. nini Ṭowong, 2. haar kind, de in luiers gewikkelde ga ṇdik; en omtrent deze laatste pop wordt nergens vermeld dat de materialen ervoor gestolen worden, ze wordt eenvoudig gemaakt en klaargezet! Het is duidelijk dat alleen een zoodanige verklaring kans kan hebben de juiste te zijn, die rekening houdt met deze verschillende behandeling der beide poppen en daarvoor een aannemelijk motief aangeeft. En deze verklaring biedt zich weer van zelf aan, wanneer men - de stelling, die het uitgangspunt werd voor onze beschouwingen, aanvaardend - inziet dat het de Javaansche twee-deeling van den stam is, die den achtergrond vormt van het spel: Nini Towong is de representante van de linkerphratrie, de gạ̣ $\mathrm{ik}$ verbeeldt de rechterstamhelft; de verhouding die bestaat tusschen de heilige plek, waar de widadari in de pop heet neer te dalen, en het erf van den vader die het $\mathrm{Ni}$ Towongfeestje geeft, is volkomen aequivalent aan die van de linker- en rechterzijde van het wajangtooneel ${ }^{1}$ ). Overal nu waar

1) Ook bij spelen in andere deelen van den Archipel leeft de primitieve tweedeeling van den stam nog voort; en de classificatie schijnt in hoofdzaken wel overal volmaakt dezelfde te zijn. Zoo bijv. op Ambon en de Oeliasers bij het zgn. hela rotan, wanneer de spelenden zich in twee partijen verdeelen, die ieder een eind van een stuk rotan-touw vasthouden en trachten elkaar over een bepaalde grens te trekken. Op de Timorlaoet-eilanden is dit spel nog duidelijk een ritus: hier moet de rechtsche (oostelijke) partij, door meerdere kracht uit te oefenen, trachten de linksche (westelijke) groep over een in den grond getrokken lijn te trekken; en men verwacht dat ten gevolge daarvan de bevruchtende Westmoesonregen zal beginnen te vallen. (Wilken, Verspreide Geschriften, III, 175, 181). De partijen heeten hier: zon en a arde, welke rangschikking overeenkomt met de Javansche classificatie, die wij in de Manikmaja aantroffen (zie boven blz. 336). Ook de strandbewoners van Seran kennen dit spel, en hier wordt het alleen bij volle paan gespeeld. (Zie F. J. P. Sachse, Het eiland Seran en zijne bewoners, 1907; blz. 163, 164). Op Halmahera is het wela-spel een onderdeel van het doodenfeest, en de benoodigdheden voor deze plechtigheid worden, 
een dergelijke stamdeeling aangetroffen is, heeft men kunnen vaststellen dat de classificatie die zich daarop vormde, zich uitstrekt over à het bestaande, en dat bij ritueele handelingen rekening wordt gehouden met een ondersteld ideëel verband tusschen de figuranten van een bepaalde groep en de zaken die in het rangschikkingssysteem tot die groep behooren ${ }^{1}$ ). Voor het "maken" van nini Towong moeten derhalve materialen gebruikt worden uit de linker-phratrie - d.w.z. voor de meisjes, die zich op de latar met het spel zullen vermaken, van buiten haar eigen groep - en, in verband met de natuurlijke rivaliteit tusschen de beide hoofdgroepen van den stam, dienen die zaken tersluiks of op min of meer gewelddadige wijze bemachtigd te worden ${ }^{2}$ ). De gandik daarentegen is thuis op de latar van dengene die het spel organiseert; hij behoort tot dezelfde groep als de spelende meisjes, en de zaken uit deze groep zijn dus voor de vervaardiging van deze figuur vanzelf aangewezen. De scheldwoorden en de ruzie, die door het wegnemen van de materialen voor de $\mathrm{Ni}$ Towong-pop plichtmatig worden uitgelokt, zijn een volmaakte parallel van het ritueele verzet bij het sluiten van elk (exogaam) huwelijk, zooals dit in verschillende deelen van Indonesië nog meer of minder duidelijk wordt aangetroffen.

Hiermede is, naar ik meen, de hypothese omtrent Ni Towong's identiteit tot volkomen zekerheid geworden; en de religieuse waarde van het spel en de geheele loop van de ceremonie hebben voor ons niets raadselachtigs meer. Wel bleven nog enkele details onbesproken, maar hoe gewichtig die wellicht ook zijn, aan de

althans voor een deel, in naburige dorpen ge r oofd". (Zie M. J. v. Baarda, Een apologie voor de dooden; in: Bijdr. Kon. Inst. dl. 69, 1914, blz. $74,85)$.

1) „L'importance de cette classification est telle qu'elle s'étend à tous les faits de la vie; on en retrouve la marque dans tous les rites principaux. Ainsi, un sorcier qui est de la phratrie Mallera ne peut se servir pour son art que des choses qui sont également Mallera", enz. E. Durkheim et M. Mauss, De quelques formes primitives declassification; in Année sociologique VI (1901-1902), 11 vlg.

2) Het is niet onwaarschijnlijk, dat ook de gevallen van ritueelen diefstal, die dr. Alb. C. Kruyt uit Celebes meedeelt in zijn opstel: Het stelen in MiddenCelebes, in: Vragen van den dag, 39.to Jaargang, 569 vlg., op deze wijze verklaard moeten worden. Men zie daar blz. 584-587.

Dl. 81 . 
hoofdzaak kunnen zij zeker niets afdoen. ${ }^{1}$ ) Wilde men in het kort de beteekenis van het bereikte resultaat kenschetsen, dan zou men die hierin kunnen zoeken dat het Ni Towong-spel gebleken is terug te gaan op een ritus die, in uiterst primitieven vorm, volkomen denzelfden bouw vertoont als het wajangspel, zonder de hooggecultiveerde verfijning die het Javaansche schimmentooneel kenmerkt, zonder ook - zoover men zien kan eenig spoor van vreemden invloed. ${ }^{2}$ ) Maar in het raam van

1) Dat de daekoen oud moet zijn, en de materialen liefst lang gebruikt en versleten, is niet onbegrijpelijk: personen en zaken worden door ouderdom altijd magisch sterker (vgl. K. Th. Preuss, Die geistige Kultur der Naturvölker, 1914, blz. 31); en het past eveneens volkomen in het ritueele karakter van het spel, dat na afloop ervan de gebezigde materialen, voor. zoover zij niet vernietigd worden, eenigen tijd buiten het gewone gebruik worden gehouden (in Jogja b.v. wordt de pop op het dak van 't huis geworpen; in Bagĕlen geschiedt dit met den waterschepper, en deze moet daar den nacht over blijven liggen): de door het ritueele gebruik in deze voorwerpen gebrachte energie moet eerst geleidelijk verminderen en verdwijnen, eer ze weer voor profane doeleinden kunnen dienen. - In mijn korte beschrijving van het spel heb ik uit de uitgebreider mededeelingen van prof. Hazeu de liedjes, die door de spelende meisjes gezongen worden, niet opgenomen; en bij mijne verklaring van de ceremonie heb ik er ook zoo goed als geen gebruik van gemaakt. Het komt mij voor, dat de hierboven voorgedragen verklaring van het spel wel eenig licht werpt op sommige duistere plaatsen in die liedjes; maar aan een doorloopenden commentaar waag ik mij toch niet; daarvoor staat de tekst ook te weinig vast. Wat het aantal der in deliedjes genoemde widadari's betreft, prof. Hazeu (o.c. 70-72) wees er reeds op dat, in allerlei combinatie's, daarin altijd weer de getallen negen en $v$ ijf verschijnen, en hij merkte tevens op, dat het getal $\mathbf{n}$ eg en van ouds op Java een soort van "heilig getal" is geweest. Hetzelfde kan gezegd worden van het getal vijf, en tevens dat de "heiligheid" van beide getallen ongetwijfeld verband houdt met de oorspronkelijke stam-indeeling. (Zie Mr. F. D. E. van Ossenbruggen, De oorsprong van het Javaansche begrip montjapat in verband met primitieve classificaties, in: Verslagen en Mededeelingen der Kon. Academie van Wetenschappen, afd. Letterk. $5^{\bullet}$ Reeks, $3^{\circ}$ deel, Eerste Stuk, 1917).

2) Ik heb overigens, bij mijn onderzoek van de verschillende, in deze verhandeling ter sprake gekomen mythen, de vraag of zij al of niet van vreemden oorsprong zijn, dan wel in hoeverre vreemde invloed erin is aan te wijzen, geheel buiten beschouwing gelaten. Dit beteekent niet, dat ik het - in de eerste plaats ethnographische - belang van een beantwoording van die vraag zou onderschatten; maar tot het vaststellen van den zin dier mythen draagt ze m.i. weinig bij. Mythen zullen altijd verklaard moeten worden van uit het milieu, waarin zij als zoodanig worden aangetroffen. "Il va de soi que nous considérons le mythe comme un fait social, e'est-à-dire comme un produit ou une manifestation normale de l'activité collective. Cela revient à dire que, sous bénifice de la démonstration qui pourra en être 
de in dit opstel voorgedragen beschouwingen houd ik het voor gewichtiger, dat opnieuw kwam vast te staan dat (op zichzelf beschouwd) het toch zoo opvallend maan-mythologisch karakter van een figuur als deze $\mathrm{Ni}$ Towong en haar in het spel telkens weer naar voren geschoven beteekenis van beschermvrouwe van huis en erf, bemiddelaarster om bevruchtenden regen te krijgen enz. enz. voor het begrijpen van haar eigenlijke waarde slechts zwakke hulpmiddelen zijn. Hun ware beteekenis krijgen deze trekken eerst, wanneer ze worden beschouwd in verband met de classificatie. Men kan zeggen: Nini Towong is de vol-wordende maan, - doch zij is dit op dezelfde wijze als Dewi Sri de godin is van de rijst, n.l. met de bijgedachte die in het logisch systeem van den primitieven Javaan daar onverbrekelijk mee verbonden is: dat $\mathrm{zij}$ in laatsten aanleg de vrouwelijke voorouder is van het Javaansche volk.

III.

In het Javaansche tooneel-repertoire neemt de lakon Moerwakala een geheel aparte plaats in, en tal van omstandigheden maken het waarschijnlijk, dat er voor wie zich een denkbeeld tracht te vormen van den zin van het Javaansche drama geen belangrijker stuk is dan dit. Men moet wel verwachten de oorspronkelijke trekken hier gaver dan elders en in juister verband bewaard te vinden; want zijn er ook al eenige andere wajangopvoeringen te noemen, die nog min of meer een ouderwetsch, religieus karakter dragen, over geen enkele ligt toch een zoo gewijde kleur als over de vertooning van deze lakon. Nooit prof. Hazeu heeft hierop de aandacht gevestigd in zijn opstel “Een Ngruwat-voorstelling» ${ }^{1}$ ) — worden de oude ritueele voorschriften zoo trouw opgevolgd als bij deze gelegenheid. De

faite, nous ne considérons pas les mythes, dans une société donnée, comme quelque chose de contingent et de surérogatoire; même empruntés, ce ne sont pas des bibelots exotiques; on ne peut pas faire abstraction, en pensant aux mythes, de la collaboration des hommes qui les ont adoptés, qui les pensent, qui les répètent et qui en somme croient à leur vérité". (Henri Hubert, in: Année sociologique VI, 1901-'02, blz, 243; spatiëering van mij).

1) G. A. J. Hazeu, Een Ngruwat-voorstelling, in Album Kern (1903), 325-332. - Men zie ook: L. Th. Mayer, Het Ngroewat en het wajangverhaal Moerwa-Kala (1906); en Inggris, Het Roewatanfeest $i_{n}$ de desa Karangdjati in Bagĕlen, in $\mathrm{Dja}$ wa, $3^{\text {de }} \mathrm{Jg}$. (1923), 45-50. 
dalang besteedt dan bijzondere zorg aan het offer, dat hij brengt vóór hij met zijn werk begint en waartoe naast bepaalde spijzen ook een kris van nauwkeurig voorgeschreven fatsoen en eenige kleedingstukken behooren. Tot driemaal toe wordt wierook gebrand. Groote aandacht wijdt de vertooner ook aan het nauwkeurig en te rechter tijd opzeggen van de vereischte tooverformulieren vóór en gedurende de opvoering, en sommige dalangs houden zich juist bij deze lakon nog aan de oude gewoonte om, vóór de vertooning aanvangt, met den dampenden wierook bij zich in een met een doek overdekte kooi te kruipen. Lang niet iedere dalang wordt dan ook in staat geacht om een zoo gewichtige vertooning te geven; bij voorkeur neemt men een ouden dalang, en het allerliefst iemand die stamt uit een geslacht dat al meerdere dalangs opleverde (toeroen ḍalang) ${ }^{1}$ ). Men mag aannemen dat een opvoering van de Moerwakala tot de meest gewijde ceremoniën behoort, die de Javaan zich denken kan; de vertooners zijn uiterst geheimzinnig met deze lakon, zij willen die niet opschrijven en voeren ze slechts op, wanneer bepaalde omstandigheden dit behoorlijk of gewenscht maken. Want dit is wel de het eerst opvallende eigenaardigheid van deze lakon en, zooals ik boven reeds opmerkte, hierom alleen reeds zal men geneigd zijn om de juistheid van de stelling, dat alle Javaansche drama's in wezen een zelfden inhoud hebben, in twijfel te blijven trekken - : er bestaat een zoo goed als absoluut verband tusschen dit ééne stuk en de zoogenaamde ngroewatceremonie. Weliswaar schijnt bij deze plechtigheid ook wel eens een andere lakon te worden opgevoerd ${ }^{2}$ ), maar de voorkeur gaat toch met groote beslistheid naar de Moerwakala, en in de Vorstenlanden ${ }^{3}$ ) is zij de eenige die in aanmerking komt; en in ieder geval: buiten de ngroewat-ceremonie zal geen dalang het wagen dit meest gewijde stuk te vertoonen ${ }^{4}$ ).

1) Inggris (l.c. 45) vermeldt, dat jonge wajangvertooners in de meening verkeeren, dat 't hun niet past, deze lakon op te voeren.

2) Hazeu, Een Ngruwat-voorstelling, 327.

8) Blijkbaar ook in Bagĕlen; zie Inggris, Roew atanfeest, 45.

- L. Th. Mayer (o.c. blz. 2) geeft aan den term ngroewat een veel ruimere technische beteekenis dan die men er gewoonlijk aan toekent. Uit zijn mededeelingen blijkt, dat hij eigenlijk iedere, een ritueele kleur dragende, opvoering van een ngelegenheidsstuk" een ngroew a t-ceremonie noemt, onverschillig met welk doel de vertooning plaats heeft. Hazeu en ook Kats (Het Javaansche Tooneel, I 108, 109) maken evenwel een scherp onderscheid 
Het doel van deze plechtigheid is het onheil te bezweren dat, naar geloofd wordt, het onvermijdelijk gevolg is van bepaalde omstandigheden of onwillekeurige handelingen, en de personen die door een zoodanigen vloek bedreigd worden daarvan te ngroewat, d.i. te verlossen. Dergelijke personen, die als 't ware overgeleverd zijn aan de willekeur van een booze macht, noemt men soekěrta ${ }^{1}$ ). Over de vraag wie tot deze categorie gerekend worden, heerscht geen volledige eenstemmigheid; de eene lijst is veel langer dan de andere ${ }^{2}$ ); maar vrij algemeen wordt toch aangenomen dat daartoe de volgende personen behooren:

1. iemand die een te vuur staanden rijstpot laat omvallen.

2. iemand die een steenen wrijfcylinder (gaṇdik) breekt.

3. iemand die een wrijfsteen (pipisan) breekt.

4. een dalang die, wanneer tijdens de wajang-opvoering het houten raam, waarop het scherm gespannen is, omvalt, daaronder bedolven wordt.

5. een eenig kind, jongen of meisje (lare ontang-anting, lare ogal-agil) ${ }^{3}$ ).

tusschen de ngroewat-ceremonie, waarvoor vrijwel alleen de Moerwakala gereserveerd is, en andere plechtigheden, waarbij andere gelegenheidsstukken worden opgevoerd. Dit onderscheid is blijkbaar aan het vervagen. (Zie Inggris, Roewaten feest, 45).

1) Prof. Hazeu (l.c. 326, nt. 2) merkt op, dat deze naam vreemd aandoet, daar het Sanskṛt sukṛta geen andere dan gunstige beteekenissen heeft; en hij vraagt zich af, of hier aan een euphemisme, aan een pantang dus, of aan een verfraaiing van het Jav. woord soekĕr (d.i. onrein; in verlegenheid zijn) gedacht moet worden. Onmogelijk is dit niet; maar het lijkt mij waarschijnlijker, dat het woord in zijn gewone beteekenis van nversierd", "opgesierd" moet worden genomen, en dat de naam zijn oorsprong heeft in de omstandigheid, dat deze getaboeëerden, ten einde meer in 't bijzonder den heilzamen invloed van de ngroewat-ceremonie te ondergaan, daarbij in ritueelen opschik dienen tegenwoordig te zijn. Inggris (l.c. 45) vermeldt, dat een kind, waarvoor het roewatanfeest gegeven wordt, gedurende het opvoeren van de lakon in een stuk wit goed gewikkeld moet zijn of bij gemis daarvan mooie kleeren moet dragen en bij den dalang zitten. - Zie ook Mayer, o.c. blz. 3. [Nadat dit opstel reeds ter publicatie was aangeboden, wezen dr. Juynboll en prof. Hazeu mij er op, dat prof. Kern (Verspr. Geschr., X, 157) aantoonde dat dit Jav. soekĕrta niet teruggaat op Skr. sukṛta, maar op Skr. svîkṛta = bemachtigd, bezeten.]

9) Zie Hazeu, 1.c. 326; Mayer, o.c. 3; Kats, o.c. 172; Inggris, 1.c. 45.

8) Voor de verklaring van deze en de volgende benamingen, zie Hazeu, 1.c. 326 . 
6. twee kinderen, een jongen en een meisje, van dezelfde ouders, die geen broeder of zuster meer hebben (lare gẹ̣ana gẹ̣ini).

7. twee kinderen, als boven, doch beiden jongens (la re o eg e r-oegěr lawang).

8. twee kinderen, als boven, doch beiden meisjes (la re

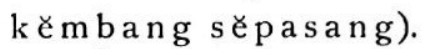

9. drie kinderen, waarvan alleen het middelste een meisje is (lare sẹñang ingapit pantjoeran).

10. drie kinderen, waarvan alleen het middelste een jongen is (lare pantjoeran ingapit sẹṇạang).

11. vijf jongens; volle broeders, die geen zuster hebben.

Men neemt aan, dat de personen, die in dezen taboe-toestand verkeeren, daaruit alleen kunnen worden verlost door een opvoering van de lakon Moerwakala, of althans door een ritueele handeling waarvan een zoodanige vertooning een integreerend deel uitmaakt. Den inhoud van dit drama kennen wij uit mededeelingen van verschillende onderzoekers ${ }^{1}$ ); zooals gewoonlijk verschillen de redacties nogal aanmerkelijk, maar toch meer in het bijwerk dan in de kern. Ik laat hieronder, als grondslag voor een nadere beschouwing, de schets van het stuk volgen, zooals prof. Hazeu die opteekende uit den mond van een ḍalang te Jogja.

Bațara Goeroe houdt audiëntie in den soeralaja (het godenverblijf), omringd door de goden Nærada, Brama, Endra, Sambo en Bajoe. Een gara-gara heeft Goeroe opmerkzaam gemaakt dat er op aarde iets bijzonders gebeurt. Nerada deelt mede dat die gara-gara veroorzaakt wordt doordat een zekere dewi Tenaga vurige ascese bedrijft midden in de zee. Dadelijk begeeft Goeroe zich daarheen, rijdende op de lěmboe Andini, en begeleid door Nerada. Zoodra Goeroe de prinses heeft gezien, wier lange haren haar eenige kleeding vormen, begeert hij haar tot vrouw; doch zij weigert, en als hij geweld wil gebruiken, vlucht zij. Heur haren fladderen in den wind, zoodat Goeroe haar in al haar schoonheid ziet. Hij gloeit van liefdesverlangen .... 't Gevolg is dat er weldra een groote d Łnawa te voorschijn komt, die eigenlijk de «kama salah» van Goeroe is. Die reus begeeft zich

1) Hazeu, l.c. 329 ; Mayer, o.c., 11; Kats, o.c. 172 ; Inggris, l.c. 45. 
tot den god, en verzoekt dezen hem een naam en kleederen te willen schenken. Goeroe noemt hem bat a r a Kala, en schenkt hem de kleederen, die vroeger gedragen waren door Karoengkala. Daarop vraagt Kala om eten, en Goeroe willigt ook dat verzoek in door de wong soek erta tot zijn voedsel te bestemmen. Kala verwijdert zich.

Zoodra Kala weg is, verwijt Nerada aan Goeroe dat hij onbezonnen heeft gehandeld door zulk een ruime volmacht aan Kala te geven. Goeroe heeft berouw, maar 't is te laat, zijn gegeven woord moet hij houden. Evenwel, Nerada weet hem over te halen een list aan te wenden. Op diens raad zoekt hij Kala op en beschrijft Kala's lichaam, zijn rug, zijn borst, zijn voorhoofd, zijn handen enz. met bepaalde formulieren (donga), als de donga's (wa)ringin soengsang, santilaheng, banjak ḍalang, sastra-binẹçati, koembala-gěni, pangloewaran, enz. Den verbaasden Kala zegt hij dat deze opschriften hem overal zullen doen kennen als den zoon van Goeroe, maar in waarheid zal ieder, die deze donga's kan lezen, Kala kunnen verhinderen de wong soekěrta tot zijn voordeel te gebruiken.

Kala gaat verder om voedsel te zoeken. Weldra ontmoet hij twee kinderen gẹ̦ana-gẹ̣ini; hij wil ze verslinden doch ze vluchten naar Mẹndang-Kamoelan. Goeroe, die Kala in 't oog heeft gehouden, besluit ḍalang te worden. Hij noemt zich ḍalang Kaṇḍboewana (volgens anderen $\mathrm{Djati}-\mathrm{W}$ asesa). Nerada wordt zijn pandjak (= nijaga) onder den naam As ऍ «m-sore en Brama wordt panggender. De wajangtoestel heet Rekamaja-majareka, de kělir heet Megamęṇ oeng, de plisir (roode rand om de kelir) koewoeng-koewoeng, de blentjong waringin soengsang, het vuur bețara soerja, de gědebog naja gangsal, de těpak-dara heeten sangga-boewana, de panggoeng bale k ̌ mbang en de gamělan Loka-nanta.

Terwijl Goeroe, Brama en Nerada als reizende wajangspelers rondzwerven in de omgeving van Meṇdang-Kamoelan, vernemen zij dat een zekere boejoet Bowal aldaar een dalang zoekt om zijn kinderen, die gẹ̦ana-gðđ̣̣ini zijn, te ngroewat. Onmiddellijk begeven zij zich daarheen, stellen de panggoeng op en maken de sadjen in orde (sarana toelak ing pangroewat). Nadat de dalang Kaṇdaboewana eerst van 's avonds tot 's morgens een willekeurig, gewoon wajangstuk heeft gespeeld, begint 
hij 's morgens de lakon Moerwakala te vertoonen, die dienen moet om te ngroewat. Terwijl hij daarmede bezig is, komt er plotseling iemand met 't bericht dat er dieven bij den kaoem van Mæṇ̣ang-Kamoelan hebben ingebroken. Bij onderzoek blijken er drie dieven te zijn: Djoegil-awalam, Soka en Langkir geheeten. De eerste wordt gevat en onthoofd; zijn hoofd wordt op een staak gestoken. De twee anderen vluchten de paringgitan binnen en zoeken bescherming bij Kjāi ḍalang, die belooft hen te zullen beschermen en zijn spel voortzet.

Doch plotseling verschijnen twee kinderen gẹdana-gẹdini, die gevlucht zijn voor bațara Kala. Op Kjāi ḍalang's bevel verschuilen ze zich tusschen de gamělan-instrumenten. Weldra komt Kala en vraagt naar de kinderen. Doch de ḍalang beweert ze nergens gezien te hebben, en speelt weer door, terwijl Kala blijft staan kijken, dicht bij 't huis, tegen een klapperboom geleund. Onverwachts gaat nu de dalang met luider stemme tooverformulieren reciteeren, n.l. die welke Goeroe vroeger op Kala's borst had geschreven: hij heeft ze slechts af te lezen. 't Duurt niet lang of Kala, wien 't aanhooren van deze mantra's een gevoel geeft alsof zijn gansche lichaam werd geroosterd, kan het niet meer uithouden en vliegt weg, de lucht in (maboer). De kinderen gẹ̣ana-gẹdini zijn gered.

Goeroe, Nerada en Brama hernemen hun godengedaante en keeren terug naar den soeralaja.

Einde van de lakon Moerwakala.

Zet men er zich nu toe om dit wonderlijke verhaal volgens de tot hiertoe met succes toegepaste methode te analyseeren, dan stuit men op ernstige moeilijkheden; en terstond zij hier erkend, dat ik er niet in slaagde om van deze (naar allen schijn voor ons onderzoek zoo belangrijke) lakon, in ha a geheel beschouwd, een interpretatie te geven die ze zou doen kennen als niet meer dan een variant van wat in den aanvang van deze verhandeling werd gesteld als schema van ieder Javaansch tooneelstuk. Ik ben overtuigd dat een zoodanige verklaring ook niet mogelijk is. En deze negatieve uitkomst is hierom zoo gewichtig, daar men de beteekenis ervan bezwaarlijk beperken kan tot deze ééne lakon, en zij wel van invloed schijnt te moeten zijn op heel onze beschouwing van het Javaansche drama in het algemeen. Want men heeft niet zonder meer het recht om 
de Moerwakala voor een geheel op zichzelf staand verschijnsel in de Javaansche tooneelletterkunde te houden; daarvoor zijn de punten van overeenkomst tusschen dit stuk en de andere lakons te talrijk en te sterk. Even goed als welk ander drama ook geeft de Moerwakala ons een strijd te aanschouwen tusschen een goede en een booze macht, waarin ten slotte de rechterpartij overwint; en ook in onderdeelen vallen de verwante en zelfs gelijke trekken terstond in het oog.

Het begin van het stuk al dadelijk zou als inleidende scène van elke lakon kunnen dienen, en de verhouding der figuren tot elkaar schijnt wel dezelfde als die wij elders voortdurend opmerkten. ${ }^{1}$ ) In Goeroe met het licht ontvlambaar gemoed en met zijn stoet van hemelsche goden is men geneigd weer den vertegenwoordiger der rechterphratrie te herkennen; hij ontsteekt in hevige liefde voor de schoone Vrouw uit de andere stamhelft, die in zware, de wereld schokkende ascese bezig is zichzelf te initiëeren. Dewi Tenaga is inderdaad de voor hem bestemde vrouw, maar de exogame tweedeeling en de omstandigheid ook dat haar inwijdingsproef eerst ten einde toe dient te worden afgelegd, dwingen haar zijn aanzoek te weigeren en zich te onttrekken aan zijn vervolging. Maar Goeroe's hartstochtelijk verlangen blijft daarom niet zonder gevolg: uit zijn "booze zaad, wordt hem een zoon geboren met het uiterlijk van een monsterachtigen reus, die den naam krijgt van Bațara Kala. Deze zoon kan wel niet anders zijn dan de mannelijke representant der linkerphratrie, en de hem gegeven naam schijnt hem nog eens scherp aan te duiden als demon van de initiatie; want telkens weer zagen wij in andere lakons de figuren, die dezen (of een daarmee samengestelden) naam voeren, in die kwaliteit optreden. ${ }^{2}$ ) - Maar hier doet zich nu het groote bezwaar op; immers in het dan volgende - belangrijkste - gedeelte van de lakon heeft onmiskenbaar het conflict der beide partijen een geheel andere beteekenis dan die in deze hypothese geëischt wordt. Het karakter der strijdende machten (Kala en Goeroe) is in de Moerwakala juist buitengewoon scherp aangegeven, en van

1) Dit gedeelte komt trouwens, zooals prof. Hazeu reeds opmerkte, vrijwel geheel overeen met een passage uit de Manikmaja (zie Winter, o.c. blz. 25 vlg.), en van welken aard de in dit mythologische geschrift verwerkte motieven zijn, trachtte ik hierboven duidelijk te maken.

2) Zie boven, blz. 321, 327, 339. 
Kala's onderstelde wezen van demon der initiatie blijkt verder hoegenaamd niets; hij is niet anders dan een booze geest, die de ongelukkige stervelingen, die door een noodlottige omstandigheid of een onwillekeurig vergrijp soek ऍrta zijn geworden, bedreigt, - Goeroe daartegenover is de heilzame macht, die hen redt.

Vele vragen doen zich thans op, die gemakkelijk in enkele samen te vatten zijn. - Ligt inderdaad in het sterk gewijde, ouderwetsche karakter van de Moerwakala-vertooning een voldoende aanwijzing om aan te nemen, dat in dit stuk het oorspronkelijk schema van het Javaansche drama zuiverder is bewaard gebleven dan in andere lakons, en de verhouding en beteekenis der figuren er beter in uitkomt dan elders? En moeten wij dus bij een poging om den zin van het wajangspel vast te stellen in de eerste plaats rekening houden met dit stuk? Is de innige samenhang van deze lakon met de ngroewat-plechtigheid op deze wijze op te vatten, dat er tusschen deze verlossingsceremonie en de wajang in het algemeen een essentiëel verband bestaat, zooals dat trouwens in de Moerwakala zelf niet onduidelijk te verstaan wordt gegeven?

Er zijn, naar ik meen, voldoende redenen aan te voeren om deze vragen ontkennend te beantwoorden. - Beschouwt men allereerst met aandacht de wijze waarop deze lakon opgevoerd wordt, dan moet het terstond opvallen, dat daarin iets zonderling tegenstrijdigs is. De lakon Moerwakala wordt uitdrukkelijk gerekend tot de wajang poerwa en wordt dan ook vertoond met het bij deze wajangsoort gebruikelijke en daarvoor passende apparaat. ${ }^{1}$ ) Maar het opmerkelijke is, dat deze toestel bij de opvoering van deze lakon - en van deze alleen - eigenlijk niet doelmatig, voor een deel zelfs hinderlijk is. Het is n.l. een vast voorschrift dat men de Moerwakala uitsluitend overdag opvoert; eerst wordt gedurende den nacht een ander, willekeurig stuk vertoond, en als 't dan licht geworden is, begint pas de lakon Moerwakala ${ }^{2}$ ). Het scherm wordt uit het raam weggenomen,

1) Zie Kats, o.c. 85, 87. - Volgens Mayer (o.c. 2) wordt de Moerwakala soms met beber-figuren vertoond, en was dit oorspronkelijk regel.

2) Zoo is het bijv. in het ouderwetsche, conservatieve Jogja (Zie Hazeu, l.c. 329). - Uit Mayer's mededeelingen moet men opmaken, dat hij van oordeel is, dat in den regel ook de Moerwakala des nachts wordt vertoond. Aan het eind van zijn bericht (o.c. 10) voegt hij hieraan toe: ${ }_{n}$ In vele streken 
daar het natuurlijk bij de vertooning zou hinderen; de (geheel overbodige) lamp blijft hangen. Heel de toestel dus, die op zijn plaats is bij de gewone opvoering in den nacht, zooals die van alle andere lakons gegeven wordt, en die daarbij onontbeerlijk is, mist hier allen zin. Men voelt dat men hier met een hybridische ceremonie te doen heeft; de volkomen doellooze aanwezigheid van rekwisieten, die alleen bij de opvoering in het nachtelijk duister haar effect hebben, stempelen de Moerwakala-vertooning tot het tegengestelde van iets gaafs en oorspronkelijks; en hierom alleen reeds moet de gedachte zich opdringen dat hier een vreemd element storend in het gewone wajang-ritueel is ingedrongen.

Iets dat hiermee vergelijkbaar is, merken we op, als we het beloop van het stuk nog eens nagaan. Wanneer ten gevolge van Bațara Goeroe's liefde voor Dewi Tenaga de booze Kala geboren is, en de laatste heeft de wong soek ̌rta tot zijn voedsel gekregen, begint Goeroe berouw te krijgen over het gevaar, dat hij zoodoende over deze ongelukkigen heeft gebracht. Nerada verzint dan een list om de fout zooveel mogelijk te herstellen, en op zijn raad beschrijft Goeroe al Kala's ledematen met bepaalde spreuken, die zoodanige tooverkracht bezitten dat al wie deze reciteert, Kala kan verhinderen de wong soekerta te verslinden. Zoo is dus, zou men zeggen, het gevaar bezworen; maar het vervolg sluit hierbij niet goed aan. Want wanneer dan twee kinderen g eḍana-g eḍin i verschijnen en voor den vreeselijken Kala op de vlucht gaan, denken zij er niet aan om die spreuken op te zeggen; en ook Goeroe, die Kala in het oog gehouden heeft, gaat niet eenvoudig dit nog wel door hem zelf geschapen - middel toepassen, maar hij besluit .... dalang te worden en de wajang te gaan vertoonen! En het eigenaardige is dan verder, dat dit wajangspel, bestaat de gewoonte, om de wajang-vertooning bij het ngroewat over dag te doen plaats hebben, en zulks met of zonder de kĕlir, al naar gelang, dat de huisheer of dalang zulks goedvindt". - Inggris (l.c. 45) bericht, dat in de desa Karangdjati het ngroewat zoowel 's nachts als overdag plaats heeft, en dat men in andere desa's van oordeel is, dat men stipt volgens de voorschriften handelt door het des nachts te doen. - In de laatste mededeeling voelt men weer, dat ook den inlander de ware reden voor het overdag vertoonen van de Moerwakala niet meer bekend is: als verklaring zegt zij niets, immers terstond moet dan de vraag rijzen, waarom de afwijking van het gewone gebruik juist bij deze lakon ontstaan is, en hoe die afwijking elders een zoo dwingend karakter kon krijgen. 
nog wel door de goden opgevoerd, niet het minste effect schijnt te hebben: Bațara Kala, die op zoek is naar de beide kinderen (die zich tusschen de gamellan-instrumenten verscholen hebben) blijft kalmpjes en in het minst niet geschokt toezien ${ }^{1}$ ). Maar wanneer dan plotseling Goeroe de mantra's, die hij zelf op Kala's lichaam geschreven heeft, af gaat lezen, moet de Booze de wijk nemen, het is of zijn lichaam geroosterd wordt en hij vliegt weg, de lucht in. Dan zijn de kinderen g ẹ̣ana-gẹ̣ini gered. - Wederom voelt men hier het hybridische, en zelfs schijnt een zekere parallelie aanwezig met wat wij zooeven opmerkten: zooals bij den ngroewat-ritus de tooneeltoestel van de wajang een overbodig en zelfs eenigermate hinderlijk element is, zoo is hier, in de lakon zelf, de wajang-vertooning iets dat nutteloos is; niet het wajangspel als zoodanig noopt Kala tot de vlucht en redt de wong soek erta, dit geschiedt uitsluitend door het reciet van de tooverkrachtige $\mathrm{mantra} \mathrm{s}^{2}$ ).

Dit alles krijgt diepere beteekenis, wanneer wij de verhouding van mythe en ritus, zooals die hier bij de ngroewat-ceremonie aan den dag komt, wat nader beschouwen. Want dan blijkt 't dat die van zoodanigen aard is, dat m.i. alleen reeds daarom deze lakon Moerwakala, wel verre van zeer oorspronkelijk te zijn, te beschouwen is als een betrekkelijk late schepping, die voor het vaststellen van den zin van het Javaansche drama van weinig waarde is. Hoeveel onverklaards er n.l. in het algemeen in de relatie van mythe en cultus ook is, als vaststaand meen ik dat kan worden aangenomen, dat de normale verhouding van een mythe en den daarbij behoorenden ritus deze is, dat zij beiden op hetzelfde plan staan, zóó dat van prioriteit van een van beiden boven de andere geen sprake is; beiden onderstellen zij dezelfde gedachten en voorstellingen, die zij op verschillende wijze (de eene in woorden, de andere in gebaren) vertolken. Maar men bemerkt terstond dat hier, bij de Moerwakala-opvoering, dit samengaan van gelijkwaardige elementen

1) Deze trek komt al heel duidelijk uit in de door Kats meegedeelde redactie (o.c. 175).

2) Teekenend is in dit verband ook Mayer's mededeeling (o.c. blz. 1, noot) dat, wanneer ter plaatse geen wajang te huren of te krijgen is, het ngroew at niet gepaard gaat met wajangspel, maar alleen bestaat in het zonder fout opzeggen van de voorgeschreven bezweringsformulieren door iemand, die daartoe in staat is. 
niet aanwezig is: de ritus is hier (of wil althans zijn) de gewone van het wajangtooneel, doch de mythe is als het ware een stap verder gegaan; zij is duidelijk posterieur aan den ritus: zij onderstelt het bestaan van de wajang en tracht zelfs op hare wijze een verklaring van het ontstaan en de beteekenis daarvan te geven. Over de waarde van deze mythische verklaring moge men denken wat men wil, vast staat in ieder geval dat zij pas ontstaan is toen de behoefte daaraan zich deed gevoelen en de beteekenis van den ritus niet meer voor ieder duidelijk was. De in de lakon Moerwakala verwerkte mythe heeft zich gevormd na en òp het wajang-ritueel; dat wil zeggen: zij kan daarvan niet het normale, oorspronkelijke thema zijn ${ }^{1}$ ).

Het hier aangevoerde geeft mij moed om - bij wijze van gissing - te stellen dat het hybridische, dat zoowel in het beloop van de lakon zelf als in de wijze waarop die opgevoerd wordt, zoo duidelijk aan het licht kwam, het gevolg is van een vermenging van twee ceremoniën die genetisch niet met elkaar samenhangen: n.l. vooreerst het gewone wajangspel, en daarnaast de ongetwijfeld ook op Java van ouds in zwang zijnde magische praktijk, dat lieden die om een of andere reden geacht werden bloot te staan aan vervolging door een booze macht, daarvan werden verlost, doordat een ter zake kundig persoon, een dioekoen, tooverkrachtige woorden en bevrijdende formulieren over hen uitsprak. Een zoodanig samenvallen van tweeërlei ritueel kan hier geen groote verwondering wekken: ook aan het wajangspel is, in verband met de gevoelens die in de verhouding der phratries tot uiting komen, inhaerent, dat het een strijd te aanschouwen geeft tusschen twee partijen, waarvan de eene een gunstiger karakter vertoont dan de andere; en al is er ook fundamenteel verschil tusschen den toestand van novieten (als hoedanig we elders de beide voorouders der stamhelften telkens weer zagen optreden) en dien van de wong soek ̌rta, er is toch ook verwantschap en overeenkomst; beide categorieën van personen zijn uitgestootenen, getaboeëerden, beide worden zij bedreigd door magisch gevaar. Toen - met het losser worden van het oude, strakke maatschappelijk verband - het juiste

1) „Bien que, en principe, le culte dérive des croyances, il réagit sur elle; le mythe se modèle souvent sur le rite afin d'en rendre compte, surtout quand le sens n'en est pas ou n'en est plus apparent". E. Durkheim, Les formes élémentaires de la vie religieuse (1912), 141. 
begrip van den zin van het wajang-ritueel verminderde en verloren ging, vervaagde van zelf ook de zeer speciale en hooge, religieuse beteekenis van den boozen, de novieten verslindenden demon der initiatie, en ten slotte moest in dezen wel de incarnatie worden gezien van allerlei vijandige, magische machten, die het menschdom-in het algemeen bedreigen ${ }^{1}$ ). Van af dit oogenblik werd het wajangspel op een andere wijze en nu eerst recht een strijd tusschen een goede en een booze macht. - Op deze wijze zou het duidelijk kunnen worden, waarom deze ééne lakon met een zoo zonderling, daarvoor niet passend apparaat en in zoo afwijkende omstandigheden opgevoerd wordt, en niettemin met zoo diep ontzag wordt behandeld; en tevens waarom juist dit ééne stuk met zoo vaste banden aan de ngroewatceremonie verbonden is.

Men kan nu de vraag stellen of in de Moerwakalavertooning, zooals wij die kennen, niets anders is overgebleven van den waren aard van het Javaansche drama dan het weinige dat hierboven werd opgemerkt over de beteekenis en de onderlinge verhouding van de figuren van Goeroe, Dewi Tenaga en Kala (zooals die in den aanvang van de lakon voorkomen) en voorts de algemeene tegenstelling der twee partijen, die in den bouw van het wajangtooneel geïmpliceerd ligt. Blijkt thans uit geen enkelen trek meer iets van die affiniteit met speciale omstandigheden in het leven van den Javaan, die de wajang-ritus dan toch oorspronkelijk gehad moet hebben? - Ik meen van wèl, en ik maak daartoe opmerkzaam op nog eenige van de door prof. Hazeu in zijn al meermalen geciteerd opstel meegedeelde gegevens.

Bij zijne opsomming van de verschillende personen die tot de wong soek ̌rta worden gerekend, schrijft hij o.a.: "Slechts gedeeltelijk tot deze rubriek behoort het geval lare dipunbadjangake $n=$ een kind dat men klein heeft gehouden, d.w.z. dat men niet, zooals gebruikelijk, kort na de geboorte het haar heeft afgeschoren; in dat geval heeft op later leeftijd, b.v. bij het huwelijk, een gedeeltelijke schering plaats, doch dan is

1) „Quand les religions régressent, les grands personnages mythiques dis. paraissent ou, du moins, ils se rapetissent; ils se rapprochent de ceux que la magie met en action de préférence. C'est qu'en effet les grandes figures divines ne peuvent se constituer ou se maintenir que là où la vie sociale a une suffisante intensité. Quand le lien social se détend, que la société s'émiette en petits groupes dispersés, les dieux se mettent au niveau de cette vie publique diminuée". M. Mauss, in Année sociologique, XII (1913), 165. 
"ngroewat» noodig». 1) En de andere mededeeling, die mij hier van belang lijkt, houdt in, dat na afloop van de Moerwakala-voorstelling de dalang zich met de personen, die moeten worden ge-roewat, begeeft naar een op het erf opgericht tentje of omheinde ruimte, waar hij ze met water, dat theoretisch uit zeven bronnen af komstig is, overgiet. Hij spreekt daarbij eenige formulieren uit, waarvan de - volgens prof. Hazeu - meest bekende aldus luidt: Tak-goejang banjoekoe sigege, Oemá kang nggoejang, Doerga kang ngosoki, Wisnoe kang ngentas, ilang larane si djabang-baji, ilang dening hjang Wisesa, d.i.: "Ik baad $u$ in mijn water dat snellen groei geeft; Oema is 't die wascht, Doerga die schoonwrijft, Wisnoe die uit het water haalt; verdwenen is de ziekte van het pasgeboren wicht, verdwenen van wege God almachtig ». - Deze tooverspreuk nu, waarin de wong soekerta "pasgeboren wichten» worden genoemd, die door een overgieting met snellen groei gevend water van een ziekte genezen worden, heeft dit is duidelijk - weinig of geen zin, wanneer men die beschouwt als genetisch behoorend bij de ngroewat-ceremonie en als zonder meer toepasselijk op de in de lijst der wong soe-


ngroewat-handeling, zooals wij die thans kennen, de wong soekërta beschouwd worden als min of meer gelijkwaardig met novieten, en dat in deze spreuk een zwakke echo doorklinkt van een oud initiatie-ritueel, dat wij in het wajangspel nog duidelijk terug meenden te vinden, dan krijgen de woorden hun volle beteekenis: gezien van het standpunt der volwaardige stamleden is de ongeïnitiëerde niet meer dan een wicht, een totaal onmondig wezen, dat door het volbrengen van de, met een ritueel $\mathrm{bad}^{2}$ ) besloten, wijdingsproef van zijn ziekte genezen wordt en eensklaps, als bij tooverslag, tot volledig

1) Hazeu, o.c. 327 .

2) De overgieting der wong soekĕrta door den dalang heeft plaats in een op het erf opgericht tentje of omheinde ruimte, een soort kobongan dus. Een dergelijke kobongan is in gebruik bij verscheidene Javaansche plechtigheden, die echter alle zonder uitzondering te beschouwen zijn als overblijfsels van crisisceremoniën; en ook bij deze gelegenheden heeft dan wel een overgieting plaats met water, dat uit zeven verschillende putten genomen is. Zie C. Snouck Hurgronje, Brieven van een Wedono-pensioen, in: Verspreide Geschriften, dl. IV. I (1924), $122,123,209,225$. 
mensch uitgroeit. Deze opvatting van den zin van het formulier vindt steun (om niet te zeggen: volkomen bevestiging) in het Javaansche woord waarmee daarin de wong soekerta worden aangeduid. Djabang-baji toch en het daarmee afwisselende botjah badjang zou men wel kunnen noemen den technischen term, den "status name» voor den "noviet, in de Javaansche mythologie. Telkens weer in de lakons en wajangverhalen wordt de stamheld of -heldin bij zijn (haar) geboorte of wedergeboorte met dit woord aangeduid: als in de M engoekoehan Ken Tisnawati uit het doosje, waarin zij opgesloten was, te voorschijn komt, is zij een djabang-baji estri; en wij zagen, dat 't als botjah badjang is, dat Nini Towong haar snel stijgende loopbaan in het spel begint ${ }^{1}$ ). De uitdrukking lare dipoen-badjangakĕn uit het eerste van de beide door prof. Hazeu meegedeelde gegevens, waarop ik zooeven opmerkzaam maakte, mogen we dan ook wel vertalen met: «een kind, dat men (abnormaal lang) ongeïnitiëerd heeft gelaten». Dat een zoodanig kind "slechts gedeeltelijk" tot de categorie der wong soek erta wordt gerekend, is thans volkomen begrijpelijk: tot de wong soek erta in engeren zin behoort het n.l. niet, maar zijn exceptioneele toestand komt toch in magische gevaarlijkheid overeen met dien van de wong soekerta ${ }^{2}$ ), en in ieder geval behoort het essentiëel tot hen voor wie een initiatie-rite en een daarbij behoorende wajang-vertooning absoluut vereischt worden. ${ }^{3}$ )

1) Zie ook boven blz. 354, nt. 2 .

2) Door het niet nakomen van een sociaal voorschift wordt men altijd min of meer een getaboeëerde. Op Java wordt ook thans aan knapen die, hoewel ze er reeds den leeftijd voor hebben, nog niet besneden zijn, het leven minder aangenaam gemaakt. (Snouck Hurgronje, Verspr. Gejschr. IV I, 207; R. Hassan Soema di Pradja, Een en ander over gebruiken bij den Soendanees, in Djawa I, 103).

s) Misschien kan er thans ook eenig licht opgaan over een duistere passage in de lakon, die ik nog geheel onbesproken liet en die ook prof. Hazeu (I.c. 331) „onduidelijk en geheel onverklaarbaar" noemt: het optreden n.l. van de drie dieven. - Terwijl Goeroe met zijn gezellen de wajang zit te vertoonen, wordt er plotseling bericht dat er ingebroken is; twee van de dieven vluchten de paring itan binnen en zoeken bescherming bij den kjaï d̦alang (Goeroe), die op zich neemt hen bij te staan. In de door Kats meegedeelde lezing (o.c. 174) mengen deze dieven zich onder de gamĕlan-spelers, en gaan - evenals de personen die ge-roewat moeten worden - de instrumenten bedienen; aan het eind gaan zij vrij uit. - Het is duidelijk, dat wij hier bij deze dieven, die door het wajangspel van Baţara Goeroe straffeloosheid verwerven, niet met 
Ik weet, dat aan de hier geleverde beschouwingen over de verhouding van wajang en $\mathrm{ng}$ roewat-ceremonie niet de waarde kan worden toegekend van een definitieve oplossing van dit vraagstuk; voor het verkrijgen van een volledig inzicht in die verhouding moet men over heel wat meer gegevens aangaande de ngroewat-plechtigheid en vooral over meer kennis van de daarbij gebezigde mantra's beschikken, dan ons thans ten dienste $\operatorname{staan}^{1}$ ). Maar wel hoop ik te hebben aannemelijk gemaakt, dat in ieder geval de afwijkende inhoud van de lakon Moerwakala geen afbreuk kan doen aan de gegrondheid van het hier ingenomen standpunt ten opzichte van het Javaansche drama. Ondanks het feit dat de vertooningen van dit stuk, meer dan van eenig ander, een gewijd karakter dragen, is het toch niet te beschouwen als een fait crucial, waarmee een onderzoek naar de beteekenis van het wajangtooneel in de eerste plaats rekening zou hebben te houden. Zoowel de lakon zelf als de wijze waarop die wordt vertoond, hebben iets zoo tweeslachtigs, dat de gedachte aan een verstoring van den normalen toestand vanzelf op moest komen; en in die verstoorde verhoudingen bleken nog verscheidene trekken aanwezig, die de hier voorgedragen opvatting van den oorspronkelijken zin van den lakon-inhoud kwamen bevestigen.

IV.

Aan het tot hiertoe in het midden gebrachte dienen nog enkele woorden te worden toegevoegd. - Verklaring van lakons

gewone misdadigers te maken hebben; zij zijn ritueele dieven. Even goed ałs de wong soekĕrta ondergaan deze dieven den heilzamen invloed van den ritus en in zekeren zin behooren zij dus tot de wong soekĕrta; maar in de opgaven, die wij van deze personen hebben, worden zij nergens vermeld. Nu hooren wij weliswaar bij de wajangvertooning niet van diefstal, maar, zooals wij boven zagen, wèl bij een daarmee in bouw volmaakt overeenkomenden ritus, het $\mathrm{Ni}$ Towong-spel. Misschien hebben wij daarom in deze, actief aan den ritus meewerkende, dieven de personen te zien die (door diefstal) dien ritus mogelijk maken, zooals dit het geval is met de kinderen, die het $\mathrm{Ni}$ Towong-spel opvoeren. De meisjes (die te voren de materialen voor het spel gestolen hebben) vormen daar het begeleidend orkest: zij zingen de liedjes en bespelen de primitieve instrumenten; hier slaan de dieven de gamĕlan. - Meer dan een gissing is dit natuurlijk niet.

1) Nadere gegevens omtrent het ngroewat en de daarbij gereciteerde spreuken zijn in uitzicht gesteld door dr. B. Schrieke. Zie Tijdschrift Bat. Gen. LXII (1923), 282.

Dl. 81 . 
en daarmee verwante verhalen, zooals ik daarin heb trachten te geven, heeft - als alle mythen-interpretatie - een subjectieven kant. Hieraan is niet geheel te ontkomen; de aard van de te behandelen stof brengt het mee ${ }^{1}$ ). Wel is - ten gevolge van wat bekend werd van den aard en de beteekenis van primitieve classificaties en van de daarin tot uiting komende logische systemen - de mogelijkheid voor waarlijk methodisch, objectief mythen-onderzoek op nauwelijks te overschatten wijze toegenomen, en is in diezelfde mate het persoonlijk element in de verklaring teruggeweken, - maar volkomen verdwenen is dit laatste toch zeker niet. Waar bewijs in strengen zin niet mogelijk is, moet men zich soms bepalen tot het voorzichtig bijeenbrengen van kleine aanwijzingen, die in het grooter verband haar waarde en juiste kleur krijgen, in de hoop hierdoor een stemming te wekken, die toegankelijk maakt voor bepaalde opvattingen. Ook al beijvert men zich dus om bij zijn onderzoek met groote omzichtigheid te werk te gaan, het blijft te vreezen dat de resultaten toch altijd slechts onder zeker voorbehoud zullen worden aanvaard; en in verscheidene gevallen, waar ik in mijn oog belangrijke details ter sprake bracht en daaraan een bepaalde, in het betoog passende, beteekenis meende te mogen toekennen, ben ik mij dan ook bewust rekening te moeten houden met de kans, dat men daarin een zekere mate van willekeur blijft zien.

Wellicht is men van oordeel, dat de aangewezen weg om de waarde van mijne conclusies te toetsen en die zoo mogelijk te versterken, thans gelegen is in het op uitgebreide schaal herhalen van het experiment, d.w.z. in het analyseeren (met behulp van de hier gevolgde methode) van telkens weer andere lakons en het vergelijken van de uitkomsten. Maar - afgezien van de vraag of een betoog als het hier geleverde door een dergelijke herhaling aan wezenlijke objectiviteit kan winnen - ik wees er boven reeds op om welke redenen van een zoodanige manier van doen in dit geval m.i. niet zoo heel veel resultaat te wachten is: de lakons, die ons voor onderzoek ten dienste staan, zijn over het geheel nu eenmaal niet te beschouwen als een ideaal materiaal om er de oorspronkelijke beteekenis van het Javaansche

1) „En tant qu'elle (la mythologie) est une oeuvre d'art, elle ne ressortit pas à la seule science des religions." E. Durkheim, Les formes élémentaires de la vie religieuse, 142. 
drama aan vast te stellen op een wijze, die voor twijfel geen ruimte meer laat.

Geheel iets anders zou het echter zijn, zoo van dit lakononderzoek niet behoefde te worden gevraagd om - alleen en op zichzelf - het objectieve bewijs te brengen van een min of meer willekeurige stelling, maar de uitkomsten ervan slechts zouden hebben te dienen om een welkome bevestiging te geven aan een opvatting die a priori reeds een hooge mate van waarschijnlijkheid vóbr zich had. Indien - scherper dan tot dusver geschiedde - zou kunnen worden vastgesteld, dat er een doorgaand, innerlijk verband bestaat tusschen den aard en den bouw van de scène, waarop zich het bewogen bestaan der Javaansche voorouders afspeelt, en de voornaamste trekken van die avonturen zelve, zóó dat deze beide elementen van het wajangtooneel elkaar onderstellen en onverbrekelijk bijeenhooren, dan kwam daarmee het boven geleverde betoog op een geheel ander plan te staan en dan behoefde de dosis welwillendheid, noodig om de daar getrokken conclusies te aanvaarden, zeker niet groot meer te zijn.

Het tooneel van het wajangspel verbeeldt - zoo stelde ik den stam-als-geheel; de streng tegenover elkaar gestelde linkeren rechterhelften daarvan verbeelden de phratries. Men kan ook hierin eene hypothese zien en niets meer; maar afwijzing ervan schijnt mij toch nauwelijks mogelijk voor wie kennis heeft genomen van de beschikbare gegevens en heeft ingezien hoe gecompliceerd hier de verhoudingen zijn. Deze op den eersten aanblik zoo simpele twee-deeling der ruimte blijkt toch bij aandachtiger bestudeering er een te zijn van fijn-genuanceerden, zeer bijzonderen aard; en neemt men in aanmerking dat de verklaring van een sociaal verschijnsel als de wajang ongetwijfeld is, niet zonder meer behoort te worden gezocht in het domein van de psychologie van het individu, maar dat men in de eerste plaats zijn aandacht heeft te richten op voorafgaande sociale verschijnselen, dan is de keus al zeer klein ${ }^{\mathbf{1}}$ ). Waar

1) „Toutes les fois qu'un phénomène social est directement expliqué par un phénomène psychique, on peut être assuré que l'explication est fausse". E. Durkheim, Les règles de la méthode sociologi que, 7e éd. (1919), 128.

"La cause déterminante d'un fait social doit être cherchée parmi les faits sociaux antécédents, et non parmi les états de la conscience individuelle." Ibidem, 135. 
anders ter wereld meent men dan dat de anonyme cuitvinders van deze tooneelschikking met haar (als onveranderlijk gesanctioneerde) deeling der ruimte in twee gelijkwaardige helften, die elkaar onderstellen en te zamen een eenheid vormen en toch ook weer elkaar hevig afstooten, daarvoor het model kan hebben gevonden dan juist in den uit zijn twee phratries opgebouwden stam? Hierin alleen was hem dit model gegeven, maar hier dan ook in volmaaktheid; in de verhouding der beide stamhelften komen overal precies deze zelfde «ambivalente» gevoelens aan den dag; ook de phratries zijn elkaars gelijken en aan elkaar gelijkwaardig; in hooge mate is in beide een gevoel van verwantschap en hoogere eenheid aanwezig; zij zijn onmisbaar voor elkaar; en toch leeft onder deze eenheid onmiskenbaar en voortdurend, zooals Howitt het uitdrukt, een sterk gevoel van "vermomde vijandschap" ${ }^{1}$ ).

$\mathrm{Nu}$ is het bekend, dat deze eenheid van den stam - daargelaten nog de eenheid in deze configuratie van twee scherp afgeteekende, tegenover elkaar gestelde helften - in de maatschappijen waar het hier om gaat, niet een voortdurend even duidelijk en gemakkelijk waarneembaar feit is. Integendeel; overal waar oorspronkelijke samenlevingen van dezen bouw nog konden worden geobserveerd, is de gewone toestand deze, dat de tot een zelfden stam behoorende totem-groepen sterk geïsoleerd, dikwijls op grooten afstand van elkaar, haar zoo goed als geheel onafhankelijk leven leiden. Ook geestelijk kunnen deze groepen ver van elkaar afstaan, zoodat zij soms niet eens elkanders taal verstaan ${ }^{2}$ ). Toch mag men aannemen, dat ook in het gewone leven steeds een gevoel van saamhoorigheid aanwezig is, doch dit blijft vrijwel latent en is voor den gewonen beschouwer onzichtbaar of ternauwernood zichtbaar. Zóó is de normale toestand; en allerlei in het leven der primitieven hoogst gewichtige gebeurtenissen (ook van ritueelen aard) kunnen plaats hebben, zonder dat dit stameenheidsgevoel uit zijn sluimering gewekt wordt. Eén gelegenheid echter is er, één telkens, na onregelmatige tusschenpoozen, terugkeerende hoogtijd, waarbij dit plotseling verandert en het bewustzijn van tot één stam te behooren, eensklaps krachtig tot uiting komt. Dit is de initiatie,

1) A. W. Howitt. The native tribes of South-East Australia (1904), 512.

9) Howitt, o.c. 513 . 
de plechtige inwijding der jongelieden in de geheimen van clan en stam. Bij alle volkjes waar men nog gelegenheid had deze ceremoniën duidelijk waar te nemen, is het vast gebruik dat deze plechtigheden, ook al gaan ze van een locale totemgroep uit, toch zich niet afspelen binnen de grenzen van die groep. De initiatie interesseert den geheelen stam en heeft plaats ten overstaan van den stam; dit laatste kan trouwens niet anders, want de oorspronkelijke toestand schijnt wel deze, dat zij geschiedde door ouderen, die behooren tot clans van de andere phratrie als waartoe de novieten zich rekenen. Zoodra men nu in de een of andere groep te rade is gegaan en het besluit is genomen, dat wederom jongelieden aan de beproeving der initiatie zullen worden onderworpen en tot volledige menschen gemaakt, wordt hiervan bericht gezonden aan alle tot denzelfden stam behoorende afdeelingen, met uitnoodiging om te bestemder tijd op een bepaalde plaats aanwezig te zijn. Dan komen van heinde en ver alle clans bijeen; zich verontschuldigen geldt voor onmogelijk of ongepast; en zij legeren zich op ceremonieele wijze, streng overeenkomstig de stamdeeling in twee phratries, zoodat bij deze gelegenheid (wij mogen bijna zeggen: bij deze gelegenheid alleen) de sociale organisatie in haar hoofdlijnen op treffende wijze zichtbaar wordt, en wel op volkomen gelijke wijze als naar mijne opvatting ditgeschiedt op het Javaansche wajangscherm. ${ }^{1}$ )

Tusschen stam-eenheid en het instituut der initiatie bestaat alzoo het nauwst denkbare verband; mag men wellicht al niet zeggen dat de stameenheid geboren is uit de inwijdingsceremoniën, dat zij er zich in heeft ontwikkeld en er door onderhouden en versterkt werd, staat vast. Toen Durkheim het vraagstuk van het ontstaan der "hooge goden» in de Australische godsdiensten behandelde, wees hij er op, dat in samenlevingen als deze de initiatie de voornaamste vorm is van stam-eeredienst, en dat dientengevolge alleen bij deze plechtigheid zich een stam-mythologie heeft kunnen ontwikkelen ${ }^{2}$ ).

1) Zie bij Spencer and Gillen (The native tribes of Central Australia, 1899, blz. 276) het plan en de beschrijving van het initiatie.terrein voor de Engwura-ceremonie bij de Arunta.

2) "Comme l'initiation est la forme principale du culte tribal, c'est seulement à cette occasion qu'une mythologie tribale pourait prendre naissance." Durkheirn, Les formes élémentaires de la vie religieuse, 420. 
Aanvaardt men nu - als eerste nuttige verdeeling van den geheelen mythenschat in een samenleving als waarvan hier steeds sprake was - de hier gesuggereerde onderscheiding in clanverhalen en stam-verhalen, dan gaat er licht op over de geheimzinnige, exclusieve voorkeur van het Javaansche tooneel voor zijn ééne, altijd weer opnieuw bewerkte mythe, en dan springt het, dunkt mij, in het oog, waarom in alle lakons, naast en boven de twee-deeling, de initiatie der hoofdfiguren het centrale thema moest zijn. Op een tooneel, geconstrueerd als het Javaansche, met zijn verdeeling der ruimte in twee gelijke terreinen van verschillende geaardheid, past geen clan-mythe, d.w.z. een verhaal, dat zich afspeelt binnen de grenzen van een afzonderlijke groep en uitsluitend werkt met wat in de classificatie aan die groep is toegewezen, - maar alleen een mythe die het geestelijke leven van den geheelen stam bestrijkt. Maar van deze stammythen - evengoed als van den ritus, waarop zij zich vormden - staan de groote lijnen onwrikbaar vast. Haar oorsprong kunnen zij verloochenen noch vergeten: geboren uit de inwijdingsfeesten ten overstaan van de op ceremoniëele wijze in twee hoofdgroepen vergaderde clans, hebben zij noodwendig in de eerste plaats te motiveeren de eenheid-intweedeeling van den stam en het instituut der initiatie. De onveranderlijkheid dezer groote lijnen sluit een welhaast oneindige variatie niet uit. De verdeeling der mythen in clanverhalen en stam-verhalen is er een van zeer algemeenen aard; zij laat ruimte - wij zagen het boven - voor meer speciale onderscheidingen in maanmythen, zonnemythen, agrarische mythen e.t.q., maar zij overspant die en brengt ze tot haar ware beteekenis terug. Doordat nu eens op het eene, dan weer op het andere element in de classificatie de nadruk gelegd werd, konden de lakons den indruk wekken absoluut heterogeen te zijn; doch dit is slechts schijn, want deze verscheidenheid tast de hoofdlijnen niet aan. Alle lakons zijn en blijven stam-mythen; in wezen bestaan zij altijd uit dezelfde - en wel de zooeven genoemde - motieven. In welke bijzondere gedaante de beide voorouders van het Javaansche volk ook optreden, het is steeds weer hun lijden, dikwijls hun tijdelijke ondergang, die de voornaamste episode vormt van hun lotgevallen. Stervend brengen zij aan hun nazaten de kostelijke cultuurgoederen; hun smartelijke ascese is hun scheppingsdaad. 
Het kan niet bevreemden, dat het begrip van de sociale beteekenis van dit heroïsch drama sinds onheuglijke tijden is verloren gegaan. Wellicht heeft klaar besef ervan nooit bestaan; denkbaar is het in ieder geval alleen te midden van zeer speciale maatschappelijke verhoudingen. Maar de religieuse waarde van het spel staat daarmee slechts in verwijderd verband; zij moest wel geleidelijk vager worden en onbestemder, maar volkomen verdwenen is zij ook thans nog niet. De vastheid van vele ritueele vormen en voorschriften, en daarmee de hoofdtrekken van de mythe, handhaafden zich tot op den huidigen dag; en men zou de historische ontwikkeling van het Javaansche tooneel kunnen kenschetsen als een voortdurend, onbewust pogen om een nieuwen inhoud te vinden, die $\min$ of meer in de oude vormen paste en aan veranderde behoeften bevrediging schonk. Over de vraag, in hoeverre die pogingen gelukten, moet ten slotte het oordeel worden gelaten aan den Javaan. Dit staat wel vast: de verre mogelijkheden van diepe tragiek, die in dit thema verborgen lagen voor wie het volkomen zou trekken binnen de sfeer van de individueele ziel, heeft geen dalang vermoed. 